\title{
University
}

Łuszczak, K., Persano, C. and Stuart, F.M. (2018) Early Cenozoic denudation of central west Britain in response to transient and permanent uplift above a mantle plume. Tectonics, 37(3), pp. 914-934.

There may be differences between this version and the published version. You are advised to consult the publisher's version if you wish to cite from it.

This is the peer reviewed version of the following article Łuszczak, K., Persano, C. and Stuart, F.M. (2018) Early Cenozoic denudation of central west Britain in response to transient and permanent uplift above a mantle plume. Tectonics, 37(3), pp. 914-934, which has been published in final form at http://dx.doi.org/10.1002/2017tc004796. This article may be used for noncommercial purposes in accordance with Wiley Terms and Conditions for SelfArchiving.

$\underline{\text { http://eprints.gla.ac.uk/157895/ }}$

Deposited on: 12 March 2018

Enlighten - Research publications by members of the University of Glasgow http://eprints.gla.ac.uk 


\section{Early Cenozoic denudation of central west Britain in response to transient and permanent uplift above a mantle plume}

K. Luszczak ${ }^{1,2} \uparrow$, C. Persano ${ }^{1}$, and F. M. Stuart ${ }^{2}$

${ }^{1}$ School of Geographical and Earth Sciences, University of Glasgow, Glasgow, UK.

${ }^{2}$ Isotope Geosciences Unit, Scottish Universities Environmental Research Centre, East Kilbride, UK.

Corresponding author: Katarzyna Luszczak (k.luszczak@twarda.pan.pl)

$\dagger$ Current address: Institute of Geological Sciences, Polish Academy of Sciences, Warsaw, Poland.

\section{Key Points:}

- Onshore central west Britain experienced 1.0-2.4 km of denudation in the latest Cretaceous - early Paleogene

- Exhumation started in the latest Cretaceous, before the onset of the North Atlantic Igneous Province magmatism

- Uplift resulted from a combined effect of transient thermal uplift from the mantle plume and magmatic underplating

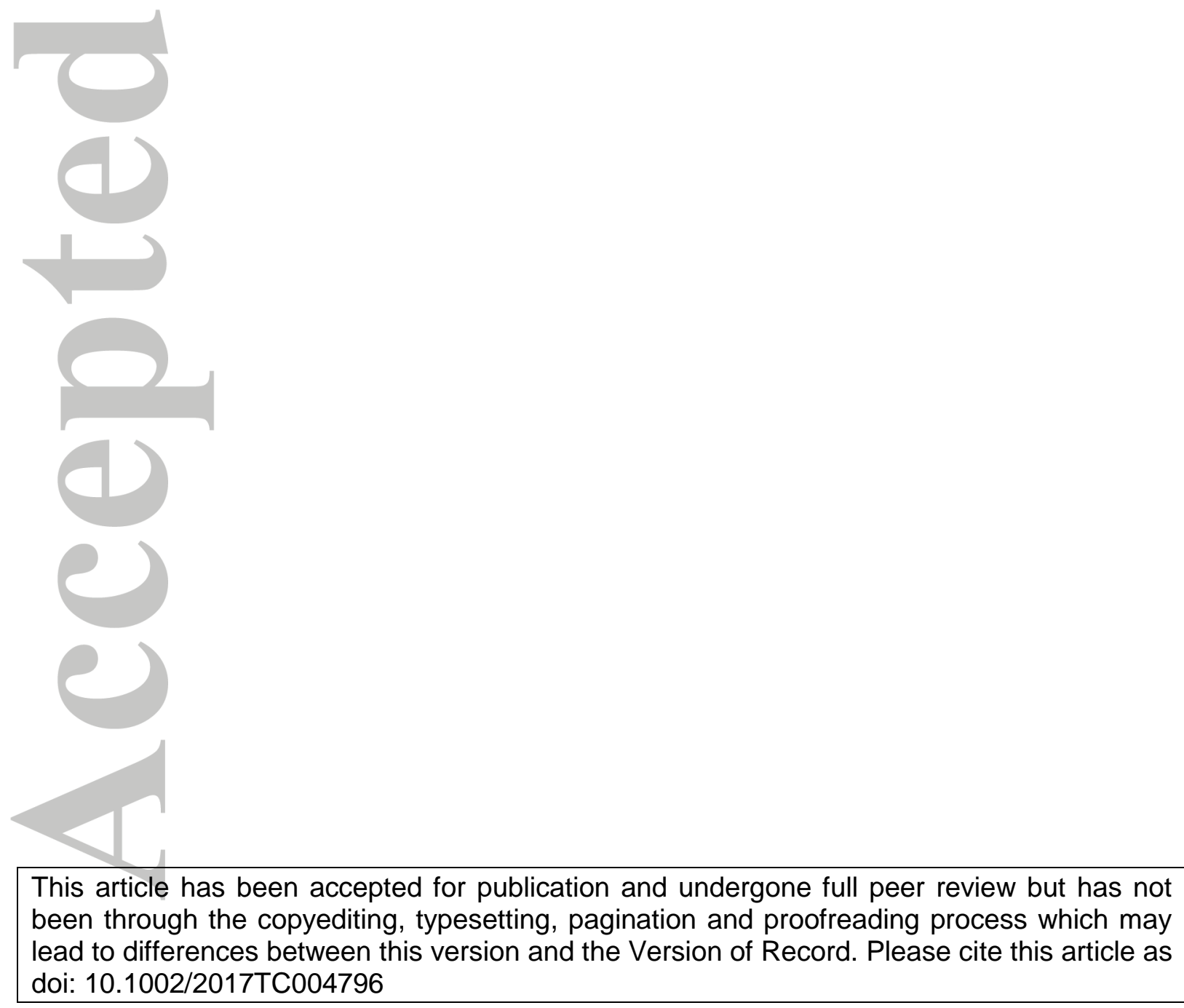

(C) 2018 American Geophysical Union. All rights reserved. 


\begin{abstract}
Upwelling mantle plumes beneath continental crust are predicted to produce difficult to quantify, modest uplift and denudation. The contribution of permanent and transient components to the uplift is also difficult to distinguish. A pulse of denudation in Britain in the Early Paleogene has been linked, although with some controversy, with the arrival of the proto-Iceland mantle plume. In this contribution we show that combining apatite and zircon $(\mathrm{U}-\mathrm{Th}-\mathrm{Sm}) / \mathrm{He}$ and apatite fission track analyses from central west Britain with numerical modeling clearly identifies a pulse of early Cenozoic denudation. The data indicate that rock uplift and denudation were centered on the northern East Irish Sea Basin and 1.0-2.4 km of rocks were removed during the latest Cretaceous-early Paleogene. Uplift and erosion appears to have started a few million years before the earliest magmatism in the region. The regional denudation pattern mirrors the distribution of low-density magmatic rocks that has been imaged in the deep crust. However, the injection of the underplating melt is not enough to account for the total denudation. An additional regional uplift of at least $300 \mathrm{~m}$ is required, which is consistent with a transient thermal effect from the hot mantle plume. The rapid exhumation event ceased by $\sim 40 \mathrm{Ma}$ and the data do not require significant Neogene exhumation.
\end{abstract}

\title{
1 Introduction
}

Rock uplift and denudation are commonly associated with tectonic processes that build mountain ranges and rift flanks (Montgomery \& Brandon, 2002; Lister et al., 1991; Persano et al, 2002; Vernon et al., 2008). However, pulses of erosion also occur in continental interiors, where they are often driven by mantle dynamics (Braun, 2010; Moucha $\&$ Forte, 2011). In this case rock uplift is more difficult to quantify as it usually has a smaller magnitude and occurs at a slower rate than at plate boundaries. Mantle plumes create transient uplift due to dynamic support by the hot, upwelling mantle and the thermal expansion of the lithosphere. Uplift may be several hundreds of meters, but when the dynamic support ceases, it leaves no permanent topographic record (Saunders et al., 2007; White \& McKenzie, 1998). Permanent uplift can occur if a layer of low-density magma is emplaced beneath or within the crust (Cox, 1993; Maclennan \& Lovell, 2002). The topography generated above mantle plumes is predicted to be low-amplitude, longwavelength and may reflect the shape of the underplating pod (Braun, 2010; Tiley et al., 2004).

A pulse of late Mesozoic-early Cenozoic exhumation of the British Isles has been proposed to have originated from either the arrival of the proto-Iceland mantle plume in the early Paleogene (Jones et al., 2002; Tiley et al., 2004; Persano et al. 2007; Cogné et al. 2016) or transmission of intra-plate stress linked with the North Atlantic break-up and the Alpine orogeny (Holford et al., 2005; Hillis et al., 2008; Stoker et al., 2010). The region surrounding the East Irish Sea Basin (EISB) was most affected; the timing and pattern of uplift reconstructed in this area favor the arrival of the proto-Iceland mantle plume as a possible origin (Cogné et al., 2016; Jones et al., 2002; Lewis et al., 1992). A large apatite fission track (AFT) dataset generated in the past decades has provided limited constraints on the exhumation history, as the temperature sensitivity of the technique $\left(60-120^{\circ} \mathrm{C}\right.$, Gleadow \& Duddy, 1981) makes it difficult to precisely quantify the cooling history of regions where the early Paleogene rock temperatures were cooler than $\sim 80^{\circ} \mathrm{C}$. The integration of apatite (U-Th$\mathrm{Sm}$ )/He with AFT data (Cogné et al., 2016; Persano et al., 2007) and better constraints on geothermal gradients prior to exhumation (Łuszczak et al., 2017) are required to make more precise estimates of the amount, timing and duration of the plume-related exhumation.

Currently there is little consensus on (i) the amount, timing and spatial variability of 
rock uplift and denudation associated with the arrival of the proto-Iceland mantle plume (Cogné et al., 2016; Davies et al., 2012; Green, 1986; 2002; Lewis et al., 1992; Saunders et al., 2007); (ii) how it is apportioned between permanent and transient uplift (Cogné et al., 2016; Hartley et al., 2011; Tiley et al., 2004; White \& Lovell, 1997) and (iii) the contribution of large scale plate tectonic processes in the Neogene (Hillis et al., 2008; Holford et al., 2005; Stoker et al., 2010) or lower crustal flow in response to lithostatic loading and subsidence in the adjacent offshore basins (Green et al., 2012; Westaway, 2010, 2017).

Here we present the first apatite and zircon (U-Th-Sm)/He (AHe and ZHe) ages, combined with AFT data of Łuszczak et al. (2017), from the region around the EISB and the English Lake District, as previous studies have shown that this region records the highest Late Cretaceous paleotemperatures (Cogné et al., 2016; Green, 1986; Lewis et al., 1992; Łuszczak et al., 2017). Taking into account the variable thermal properties of the local rocks, we quantify the amount of early Paleogene denudation and its spatial distribution, and determine the contribution from permanent (magmatic underplating-driven) and transient (thermal/dynamic-driven) rock uplift.

\section{Study area and methods}

2.1 Study area and sampling strategy

Establishing the Cenozoic history of Britain is hindered by the paucity of Late Mesozoic and Cenozoic sedimentary rocks. The latter crop out onshore only in south-east England. The near-complete absence of Cenozoic sedimentary cover across most of Great Britain is a consequence of Cenozoic tilting to the south-east (Cope, 1994). Several periods of uplift and denudation have affected the region since the Variscan orogeny, notably in the Jurassic, Early Cretaceous, early Paleogene and Neogene (Cogné et al., 2014; Green et al., 1997; Holford et al., 2005; Stoker et al., 2010). The early Paleogene event seems to have been widespread and is coincident with the emplacement of large magmatic centers in $\mathrm{W}$ Scotland and Ireland, W and E Greenland and NE Canada, related to the arrival of the protoIceland mantle plume (Figure 1a) (Saunders et al., 2007; Stuart et al., 2000).

Away from the magmatic centers, the most intense early Paleogene cooling in Britain is recorded in the English Lake District and the area surrounding the EISB (Green, 1986; Lewis et al., 1992; Łuszczak et al., 2017). The region is underlain by a pod of magmatic material that is up to $7 \mathrm{~km}$ thick (Figure 1a) (Al-Kindi et al., 2003; Tomlinson et al., 2006). Early studies predicted more than $3 \mathrm{~km}$ of denudation (Green, 1986; Lewis et al., 1992), but recent work suggests that this is closer to $1-2 \mathrm{~km}$, a result of the erosion of a low conductivity late Mesozoic sedimentary blanket, overlying a heat producing granite batholith (Łuszczak et al., 2017).

The study area comprises the three moderately elevated regions in central west Britain, surrounding the EISB: the Southern Uplands in south Scotland, the Lake District in north-west England, and north Wales (Figure 1). All regions are characterized by the absence of sedimentary rocks younger than early Paleozoic and are separated by early Mesozoic basins, e.g. EISB, Solway Firth Basin, Cheshire Basin. In order to obtain good quality, clear, prismatic apatite crystals suitable for AHe analysis, the samples were collected mostly from intrusive rocks. In the Lake District and south Scotland this meant sampling Late SilurianEarly Devonian (Caledonian) granite batholiths (Brown et al., 1968; Rundle, 1979) and Ordovician intrusive bodies in north Wales (Croudace, 1982). The sampling strategy aimed to: (i) explore the link between cooling histories and the location of the heat producing granite batholiths, and (ii) unravel the spatial distribution of the early Paleogene cooling across the region, with the intention of determining how cooling histories vary with the 
thickness of the underplating magmatic rock, and in proximity to large fault zones (especially in south Scotland).

ZHe analyses were performed on four samples that were at more than $110^{\circ} \mathrm{C}$ prior to the early Paleogene exhumation (Green, 1986; Green et al., 1997; Łuszczak et al., 2017). Crystal selection was based on the zircon shape, size and quality.

The youngest AFT ages (50-70 Ma) are from the Lake District and the Criffell pluton (Luszczak et al., 2017). AFT ages increase northwards in south Scotland and southwards in north Wales, exceeding $200 \mathrm{Ma}$ in the northernmost flank of the Southern Uplands and in the Cheviot block (Figure 1). All ages are substantially younger than the emplacement age of the intrusions, which, in most cases, occurred in the Ordovician to Lower Devonian, at 400-480 Ma (Croudace 1982; Brown et al., 1968; Rundle, 1979). Fission track length distributions in the area with young ages are generally unimodal, with small standard deviation and long mean track lengths. Moving northwards and southwards, they become wider and the mean track lengths shorter, as the ages increase (Luszczak et al., 2017).

\subsection{Thermochronology}

Combining AFT data with $\mathrm{AHe}$ and $\mathrm{ZHe}$ ages permits tracing of the cooling history of rock masses from $\sim 200^{\circ} \mathrm{C}(\mathrm{ZHe})$ to $\sim 40^{\circ} \mathrm{C}$ (AHe). Few AHe ages have been measured in Britain (Cogné et al., 2016; Persano et al., 2007) and none in the Lake District. ZHe analyses had not yet been carried out in the study region. Same-sample AHe and AFT data are crucial for unraveling the low temperature thermal history, and ZHe ages are essential, where the AFT data indicate Cenozoic cooling from more than $110^{\circ} \mathrm{C}$.

Apatite and zircon crystals were separated using standard magnetic and gravity mineral separation methods. The grains for analysis were picked and packed into Pt foil tubes and analyzed using procedure given in the Supporting Information. The age uncertainty was propagated through the age calculation and usually it was smaller than the observed dispersion of standards. In such cases, the AHe age uncertainty is given as $6 \%( \pm 1 \sigma)$, based on the reproducibility of Durango apatite aliquots, and as $10 \%( \pm 1 \sigma)$ for the ZHe ages, based on the reproducibility of Fish Canyon Tuff zircon aliquots.

\section{Thermochronometric data}

\subsection{Apatite (U-Th-Sm)/He data}

A total of 20 samples were analyzed for AHe: 4 from the Lake District, 11 from southern Scotland and 5 from north Wales. The number of aliquots analyzed per sample varies from 4 to 25 and most aliquots are single-grain. Multi-grain aliquots were prepared for samples LD12, WL02 and WL05, which are characterized by low $(<5 \mathrm{ppm})$ effective uranium (eU) and small (usually $<70 \mu \mathrm{m}$ ) grain size; with these characteristics, single-grain aliquots would have been associated with large analytical uncertainties. The raw AHe ages were corrected for the $\alpha$-recoil effect using the free software of Gautheron and Tassan-Got (2010). However, unless directly stated, the raw age is used in the discussion, as the $\alpha$-recoil correction may lead to over-correction due to a complex interaction of $\alpha$-ejection with radiation damage, zonation and the thermal diffusion of helium in apatite (Brown et al., 2013; Gautheron et al., 2012). The uncorrected ages are used as an input to the inverse modeling; the effect of $\alpha$-ejection is accounted for by the software during the modeling process (Gallagher, 2012). All uncertainties are at the $1 \sigma$ level.

AHe ages (Table 1) are plotted vs. eU and grain size in Figures S1 and S2 in the Supporting Information. The single aliquot uncorrected AHe ages from the study area vary from 19.7 to $109.0 \mathrm{Ma}$ ( $\alpha$-ejection corrected: $25.0-168.8 \mathrm{Ma}$ ), with the majority of ages 
between 30-60 Ma (corrected: 50-80 Ma). All ages are significantly younger than the emplacement age of the intrusions ( 400 Ma) (Brown et al., 1968; Rundle, 1979).

In the Lake District, the ages are generally similar or slightly younger than the corresponding AFT age. The uncorrected single-grain ages in the region vary from $19.7 \pm 2.5$ Ma to $66.5 \pm 8.4 \mathrm{Ma}$ and the corrected ages from 25.0 $\pm 3.0 \mathrm{Ma}$ to $90.4 \pm 10.8 \mathrm{Ma}$. Some corrected AHe ages of LD12 and LD18 are older than the AFT age, although similar to the other AHe ages in the region. This may be due to inaccuracies intrinsic to the recoil correction or to the fact that the AFT ages of these two samples are poorly constrained. There are no clear trends between the AHe ages and grain sizes or eU (Figures S1 and S2).

The majority of AHe ages from southern Scotland are 60-80 Ma. Uncorrected ages vary from 24.8 to $109.0 \mathrm{Ma}$ and the corrected ages from 31.3 to $168.8 \mathrm{Ma}$. The AHe ages are similar to the corresponding AFT age in the Criffell pluton, and younger than the corresponding AFT ages in other localities, with the exception of the Fleet granite, where most of the uncorrected ages are older than the AFT age. Given that this occurs in all grains from this pluton, it may be related to either a unique chemical composition of the apatites (Gautheron et al., 2013) or to He implantation, e.g. from Fe-U-Th rich coatings (Murray et al., 2014). AHe ages from the Fleet granite were not used in the thermal modeling.

Dispersion of single-grain ages varies from 3 to $28 \%$ and, in general, increases northwards. A positive correlation between the AHe ages and grain size is present in GAL14 $\left(\mathrm{R}^{2}=0.64\right)$ and SL01 $\left(R^{2}=0.67\right)$ (Figure S1), but it is mostly due to the impact of $\alpha$-ejection. Other samples show weak positive correlations or no trend. There is no clear correlation between AHe ages and eU (Figure S2).

AHe ages from north Wales are younger than corresponding AFT ages. The uncorrected ages vary from $21.2 \pm 2.5 \mathrm{Ma}$ to $77.2 \pm 13.5 \mathrm{Ma}$ and corrected ages from $27.8 \pm$ 3.2 Ma to $135.9 \pm 19.4 \mathrm{Ma}$. There is a strong positive correlation of the ages with $\mathrm{eU}$ in WL02 $\left(R^{2}=0.92\right)$ and a negative correlation in WL06 $\left(R^{2}=0.46\right)$ and WL08 $\left(R^{2}=0.70\right)$ (Figure $\mathrm{S} 2)$. The ages of WL05 $\left(\mathrm{R}^{2}=0.45\right)$ and WL08 $\left(\mathrm{R}^{2}=0.53\right)$ show also a weak positive correlation with grain size (Figure $\mathrm{S} 1$ ).

\subsection{Zircon $(\mathrm{U}-\mathrm{Th}) / \mathrm{He}$ data}

ZHe analyses were performed on four samples. The number of aliquots analyzed per sample varies from 3 to 5 . The ages were corrected for the $\alpha$-recoil effect, using the free software of Gautheron and Tassan-Got (2010). The uncorrected ages are used in the thermal modeling.

ZHe ages vary from 78.3 to $416.0 \mathrm{Ma}$ (corrected ages 102.6-562.9 Ma), with the majority of ages of c. $400 \mathrm{Ma}$ (Table 2), which corresponds to the time of intrusion emplacement ( 400 Ma) (Brown et al., 1968; Rundle, 1979). All aliquots from the Skiddaw granite in the central Lake District and one aliquot from the Criffell granite on the south coast of Scotland yield ages that are younger than $200 \mathrm{Ma}$; they are characterized by a high eU, $>1000 \mathrm{ppm}$. Despite a small number of analyzed crystals, a strong positive correlation with grain size can be observed in LD01 and LD10 $\left(R^{2}=0.92\right.$ and $R^{2}=0.83$, respectively), whereas LD01 and GAL14 show a strong negative correlation with eU $\left(\mathrm{R}^{2}=0.97\right.$ and $\mathrm{R}^{2}=$ 0.86 , respectively) (Figures S3 and S4).

\subsection{Data summary}

Figure 2a shows a quasi-north-south oriented section of AFT and AHe ages (see Figure $1 \mathrm{~b}$ for profile location). In the south coast of the Southern Uplands and in the Lake District, the AFT and AHe ages are similar (50-70 Ma) and they increase outwards. The AFT ages form a characteristic U-shape pattern. The AHe ages show a broad U-shape that is much 
less well defined, but in general, the AHe age dispersion increases with increasing AFT age. The ZHe ages in all plutons exhibit a significant range (100-400 Ma); the oldest is within the uncertainty of pluton emplacement. ZHe ages decrease significantly when eU values are greater than $700 \mathrm{ppm}$ and display a negative correlation with eU at 700-2000 ppm (Figure $2 b)$. This is consistent with the accumulation of radiation damage in the high- $U$ zircon crystals and numerical modeling has demonstrated that this can be observed when the rock has experienced a phase of reheating (Guenthner et al., 2013).

\section{Quantifying uplift and denudation}

\subsection{Thermal histories}

The AHe and ZHe ages were modeled together with the AFT data of Łuszczak et al. (2017) using the QTQt software (Gallagher, 2012) to extract thermal histories for each sample. All fission track data were modeled using the multi-kinetic annealing model of Ketcham et al. (2007), using c-axis projected lengths and compositionally dependent initial track length, estimated using the D-Par values for each grain (average of at least 5 measurements per grain). The He diffusion in apatite and zircons crystals was modeled incorporating the effect of radiation damage, using the algorithm of Gautheron et al. (2009) for the AHe data and the model of Guenthner et al. (2013) for the ZHe data. Three thermal histories are given for each sample: (i) expected model, which is a weighted mean model, where weighting is provided by the posterior probability; (ii) maximum likelihood model, which is the model that best fits the data; and (iii) maximum posterior model, which is the model with the maximum posterior probability (Gallagher, 2017). In the QTQt-adopted Bayesian approach, simple solutions with adequate fit to the data are preferred and, therefore, the expected model is considered to be the best representation of the sample thermal history (Gallagher, 2012).

All models were run for at least 200,000 iterations ('post-burn-in') after discarding initial 100,000 iterations ('burn in'). The Bayesian transdimensional Markov chain Monte Carlo (MCMC) inversion scheme was applied and the number of time-temperature points in a thermal history, i.e. the model complexity, was not specified in advance, but inferred from the data (Gallagher, 2017). The general prior time-temperature box was set at temperatures of $75 \pm 75^{\circ} \mathrm{C}$ and $120 \pm 120^{\circ} \mathrm{C}$, for AFT $+\mathrm{AHe}$ and for AHe $+\mathrm{AFT}+\mathrm{ZHe}$ data, respectively. The range set for time was based on the oldest observed age (the oldest age \pm the oldest age) or the intrusion emplacement age, whichever was the youngest. For intrusive rocks, the emplacement age was added as an additional thermal constraint. For the two sedimentary rocks the main input constraint is the deposition age. The detailed thermal constraints for all models are provided in the Supporting Information.

Model-derived paleotemperatures for each locality and exemplary thermal models are presented in Figure 3. The thermal models are from the samples with the largest datasets and, therefore, are considered to be the best representation for each site. An expected model with 95\% credible intervals is shown for each sample, along with the posterior probability distribution. Thermal models for all samples accompanied by maximum likelihood and maximum posterior models are shown in Figure S5 in the Supporting Information.

The models show that in the Late Cretaceous the rocks currently at the surface were at temperatures that range from $120-140^{\circ} \mathrm{C}$ in the Lake District and the south coast of Scotland, decreasing northwards and southwards to $\sim 60^{\circ} \mathrm{C}$. The Lake District plutons cooled rapidly in the latest Cretaceous-early Paleogene. The exemplary models from the region (Carrock LD02 and Shap - LD01) are similar. The Carrock intrusion cooled to less than $120^{\circ} \mathrm{C}$ shortly after emplacement and was likely reheated prior to the final cooling at the end of the 
Cretaceous. The rapid cooling from $120^{\circ} \mathrm{C}$ (or $140^{\circ} \mathrm{C}$ in the case of the maximum likelihood model) started at $65-75 \mathrm{Ma}$, at a rate of $3-4^{\circ} \mathrm{C} / \mathrm{Myr}$. The t-T paths for the Shap granite show post-emplacement cooling to $40-140^{\circ} \mathrm{C}$ that ended at $250-300 \mathrm{Ma}$. Thereafter the rocks were probably reheated until $\sim 90 \mathrm{Ma}$ to $\sim 130^{\circ} \mathrm{C}$. The presence of the reheating phase is supported by the negative correlation between $\mathrm{ZHe}$ ages and eU. This time marks the onset of a rapid cooling episode, $\sim 10 \mathrm{Ma}$ earlier than at Carrock. The maximum likelihood model suggests that the cooling started slightly later, $70 \mathrm{Ma}$, and from slightly lower temperatures of $\sim 110^{\circ} \mathrm{C}$. The early Cenozoic cooling rate estimated from the expected model was $\sim 2^{\circ} \mathrm{C} / \mathrm{Myr}$ and decreased after $\sim 50 \mathrm{Ma}$.

The rocks from south Scotland display a range of thermal histories that imply a variation in the magnitude of Cenozoic cooling. Figure 3 shows three exemplary models (Criffell - GAL14; Corsewall Point - GAL11 and Loch Doon - GAL01). The Criffell pluton cooled after emplacement to less than $150^{\circ} \mathrm{C}$. After $200 \mathrm{Ma}$ it was buried, reaching $\sim 140^{\circ} \mathrm{C}$ in the Late Cretaceous. The reheating is required to produce the observed range of $\mathrm{ZHe}$ ages, as well as the apparent negative ages-eU correlation. Rapid cooling $\left(5-10^{\circ} \mathrm{C} / \mathrm{Myr}\right)$ started at 70 $75 \mathrm{Ma}$. The Loch Doon pluton (GAL01) stayed in the partial annealing zone (PAZ, 60$120^{\circ} \mathrm{C}$ ) between $\sim 250 \mathrm{Ma}$ and $\sim 120 \mathrm{Ma}$; then it cooled monotonically from $\sim 80^{\circ} \mathrm{C}$. Though poorly resolved, the maximum likelihood model suggests that the final acceleration in the cooling rate began at $\sim 70 \mathrm{Ma}$. GAL11 from Corsewall Point yields similar AFT age to the sample from Loch Doon; however, the modeled thermal histories are more complex. After deposition (458 $\pm 2 \mathrm{Ma}$; Bluck et al., 2006), the rock was reheated to $\sim 120^{\circ} \mathrm{C}$ at $260-280 \mathrm{Ma}$. After a cooling episode between 260 and $200 \mathrm{Ma}$, the rock remained within the PAZ or at even lower temperatures and has been reheated again prior to the next cooling event. The expected thermal histories show a slow monotonic cooling in the last $60-70 \mathrm{Ma}$ from $\sim 70^{\circ} \mathrm{C}$. The posterior distribution, supported by the maximum likelihood model, indicates a probability that there was a rapid cooling event at $\sim 60 \mathrm{Ma}\left(\sim 1.5^{\circ} \mathrm{C} / \mathrm{Myr}\right)$, followed by rapid cooling in the last few million years, from $40-50^{\circ} \mathrm{C}$.

The model from north Wales (Penmaenmawr - WL08) shows that the rock entered the PAZ at $\sim 200 \mathrm{Ma}$, then cooled to $\sim 50^{\circ} \mathrm{C}$. Subsequent reheating to $70-80^{\circ} \mathrm{C}$ was followed by cooling in the last 60-70 Myr. A rapid cooling event in the early Paleogene is, however, possible based on the posterior distribution and the maximum likelihood model.

The AFT data are well predicted by the models. In several cases the predicted AHe ages are younger than the observed data, which often display a large amount of dispersion that remains unresolved. Over-dispersion of AHe ages is common. The effects of grain size, radiation damage, and broken grains (Beucher et al., 2013; Brown et al., 2013; Flowers et al., 2009; Gautheron et al., 2009) can be taken into account during the modeling phase, but are still not ideally parameterized. Other factors such as compositional heterogeneity, zonation and He implantation (Farley et al., 2011; Gautheron et al., 2012, 2013) cannot be yet accounted for in the modeling. When modeling the data, we used the age resampling approach, recommended when uncertainties are poorly known (Gallagher, 2012, 2017).

Summary: The change from reheating to cooling or acceleration of the cooling rate in the latest Cretaceous/earliest Paleogene is resolved in most thermal history models (Figure 4). Late Cretaceous temperatures are the highest in the Criffell pluton $\left(\sim 140^{\circ} \mathrm{C}\right)$ and in the Lake District $\left(110-120^{\circ} \mathrm{C}\right)$. Here, well resolved rapid cooling started at 65-70 Ma.

Paleotemperatures decrease to less than $60^{\circ} \mathrm{C}$ to the north (in southern Scotland) and south (in northern Wales), and the presence of the clear cooling episode in the latest Cretaceous early Paleogene becomes more difficult to resolve. The rapid cooling event is finished by 40 $45 \mathrm{Ma}$, when paleotemperatures of $20-30^{\circ} \mathrm{C}$ are attained. Most models provide evidence for 
Late Mesozoic reheating. This is coincident with regional subsidence and widespread deposition of chalk (Figure 4). Other thermal events resolved by the models correlate with regional deposition or uplift events (e.g. the Late Cimmerian unconformity, Figure 4); however, they are poorly resolved. A pulse of cooling in the Neogene is evident only in a few models from south Scotland, suggesting that this cooling episode, if present, was localized and, in most places, below the detection limit of the low temperature thermochronometers.

\subsection{Converting cooling into denudation}

Converting cooling to denudation requires knowledge of the paleo-geothermal gradient. Most studies assume $25-30^{\circ} \mathrm{C} / \mathrm{km}$ (Cogné et al., 2016; Green, 1986; Lewis et al., 1992), although $\sim 60^{\circ} \mathrm{C} / \mathrm{km}$ caused by enhanced heat flow due to magmatic underplating has been proposed (Green, 2002, Green et al., 2012). Numerical models indicate that, for the given thickness and depth of the underplated material, the heat would not propagate fast enough to affect the upper crust, irrespective of the mode of intrusion (Brown et al., 1994, Łuszczak et al., 2017).

High Late Cretaceous paleotemperatures in the Lake District generated by high heat flow and erosion of low conductivity sedimentary rocks has been proposed in the past (Chadwick et al., 1994; Holliday, 1993). This concept was recently tested by Łuszczak et al. (2017) who concluded that the paleotemperature pattern can be explained by high heat production in the Lake District batholith and the blanketing effect of low-conductivity Late Mesozoic sedimentary rocks, without invoking an elevated basal heat flow. The total Cenozoic denudation was estimated to be $1.25-2.25 \mathrm{~km}$, of which $\sim 1 \mathrm{~km}$ was composed by low conductivity sedimentary rocks. These values are consistent with the $0.7-1.75 \mathrm{~km}$ of sedimentary cover, including $0.3-0.6 \mathrm{~km}$ of chalk, estimated using stratigraphic correlation from surrounding basins (Holliday, 1993). The model of Łuszczak et al. (2017) cannot be taken as a comprehensive estimation of regional denudation. The most important simplifications are: the use of only AFT data; a lack of pre-Cenozoic cooling and reheating events; the assumption of a spatially uniform thickness of the sedimentary blanket and of its thermal properties. For instance, the Lake District, southern Scotland and northern Wales have been structural highs throughout the Mesozoic and they must have accumulated a thinner sedimentary cover than the surrounding basins (Hancock, 1975; Holliday, 1993; Ziegler, 1988).

We use the 1-D code of heat transfer used by Łuszczak et al. (2017) and calculate denudation for each locality using paleotemperatures obtained from inverse modeling in QTQt (expected model) and locally variable thickness and composition of eroded rock section (for details, see the Supporting Information). The thickness of the sedimentary rocks is an input parameter and the thickness of the eroded basement is calculated as the difference between the total denudation required to obtain the observed cooling amount and the assumed sedimentary cover. The total denudation is, therefore, the sum of the eroded sedimentary layer and of the eroded basement. The modeled sedimentary cover consists of two layers, one of chalk and the other of 'other sediments' with thermal conductivity of $1 \mathrm{~W} / \mathrm{m} / \mathrm{K}$ and 2 $\mathrm{W} / \mathrm{m} / \mathrm{K}$, respectively; this scenario allows for vertical variations of the geothermal gradient to be considered. The term 'other sediments' refers to the pre-Late Cretaceous cover, which is mainly composed of Lower Jurassic and Triassic limestones, mudstones and sandstones (Downing \& Gray, 1986; Holliday, 1993). The thickness of the Mesozoic rocks in the Lake District was taken after Holliday (1993) and for other localities is based on values for the Lake District and comparison with the paleogeographical maps of Ziegler (1988). The results of the modeling are given in Table 3 and the resulting denudation maps are shown in Figure 5 . 
We perform the same calculation for the EISB, using paleo-temperatures of $105^{\circ} \mathrm{C}$ and $95^{\circ} \mathrm{C}$ from Lewis et al. (1992), and for the Isle of Man and east Ireland, using paleotemperatures of $80^{\circ} \mathrm{C}$ and $60^{\circ} \mathrm{C}$ from Cogné et al. (2016). The EISB values are taken from the map that presents paleo-temperatures from the AFT well data extrapolated to the surface (Fig. 3 in Lewis et al., 1992). The data from Ireland and the Isle of Man are obtained from thermal models that are based on AFT data from quasi-vertical profiles; the used values are from the top sample. Our estimates of denudation in the EISB, 1.5-2.1 km, are more than $1 \mathrm{~km}$ lower than the denudation estimates of Lewis et al. (1992) calculated assuming constant, presentday geothermal gradient and they are in good agreement with values derived from other methods, such as sonic velocity analysis, inverse modeling of stacking velocity data from seismic reflection data and compaction studies (Holford et al., 2005; Jackson \& Mulholland, 1993; Mackay \& White, 2006; Rowley \& White, 1998; Ware \& Turner, 2002).

The maximum denudation, $2.0-2.4 \mathrm{~km}$, is recorded for the region around the Criffell pluton in SW Scotland and it decreases northwards to 1.0-1.2 km in the Southern Uplands (Figure 5). Denudation of 1.6-2.1 km is recorded for the Lake District, with the lowest amount recorded in the central part of the block. In northern Wales, denudation ranges from 1.0 to $1.7 \mathrm{~km}$. Estimates of early Paleogene denudation in east Ireland and the Isle of Man are lower than those of Cogné et al. (2016) as we take into account both variable geothermal gradient in the eroded rocks, and, in east Ireland, relatively high heat flow due to the presence of heat-producing granite batholiths (Farrell et al., 2015).

\subsection{Underplating derived uplift}

The observed pattern of denudation is consistent with other studies (Cogné et al., 2016; Jones et al., 2002; Lewis et al., 1992) and broadly reflects the thickness of magmatic underplating beneath the region (Al-Kindi et al., 2003, Tomlinson et al., 2006). This link is often taken as evidence that rock uplift and denudation were triggered by underplating (e.g. Cogné et al., 2016).

The amount of denudation estimated from the thickness of the underplated material derived from the seismic data of Al-Kindi et al. (2003) reproduces the denudation estimates of the EISB; however, it predicts no denudation onshore, where the thickness of the underplating pod, at most, isostatically balances the existing topography (Tiley et al., 2004). This casts doubt on the hypothesis that the early Paleogene uplift in onshore Britain was driven by underplating of mantle plume melts. The model, however, does not accommodate for variable water depth prior to the onset of the uplift episode, nor a difference in rocks densities onshore and offshore. The lithospheric elastic thickness in central Britain is so low $(5 \pm 2 \mathrm{~km})$ (Tiley et al., 2003) that local variation in topography, water depth and density of the eroded material may affect the isostatic response of the lithosphere to uplift and denudation.

We assume the average present-day topography in the Lake District of $250 \mathrm{~m}$ and we use location-specific values of water depth and density of eroded material to calculate the amount of denudation driven by underplating. The Late Cretaceous sea was most likely 100 600 m deep (Hancock, 1975). As the Lake District probably formed a submerged structural high (Akhurst et al., 1997; Ziegler, 1988), we assume a minimum water depth of $100 \mathrm{~m}$, and $400 \mathrm{~m}$ for the EISB. The central and northern parts of south Scotland may have remained emergent during the Late Cretaceous transgression (Hancock, 1975; Ziegler, 1988); we assume water depth of $0-100 \mathrm{~m}$.

The density of the eroded rock is the most important factor in controlling isostatic response to denudation, exerting a major control on the evolution of topographic relief (Braun et al., 2014). The basement rocks in the Lake District are mainly Ordovician-Silurian 
volcanics and Early Devonian granites, with densities $\sim 2.7-2.8 \mathrm{~g} / \mathrm{cm}^{3}$ and $\sim 2.6-2.7 \mathrm{~g} / \mathrm{cm}^{3}$, respectively (Bott, 1974). The rocks being eroded in the EISB, on the other hand, were mostly Lower Mesozoic sandstones and mudstones, $2.0-2.4 \mathrm{~g} / \mathrm{cm}^{3}$ (Bott, 1974, Hobbs et al., 2002).

Here we assume Airy isostasy and calculate denudation from magmatic underplating thickness, present-day topography and initial water depth (modified from White \& Lovell, 1997; Fig. S6a):

$D=\left(\frac{\rho_{m}-\rho_{x}}{\rho_{m}-\rho_{s}}\right) X-\left(\frac{\rho_{m}}{\rho_{m}-\rho_{s}}\right) T-\left(\frac{\rho_{m}-\rho_{w}}{\rho_{m}-\rho_{s}}\right) W$

where $\mathrm{D}$ is the amount of denudation, $\mathrm{X}$ is the thickness of magmatic underplating estimated from the maps of Al-Kindi et al., (2003) and Tomlinson et al., (2006); T is the present-day topography; $\mathrm{W}$ is water depth prior the emplacement of the underplating layer as discussed in the previous paragraph; $\rho_{\mathrm{m}}$ is density of mantle/asthenosphere; $\rho_{\mathrm{s}}$ is density of upper crustal rocks, usually sediments; $\rho_{\mathrm{w}}$ is density of water $\left(1.0 \mathrm{~g} / \mathrm{cm}^{3}\right)$; and $\rho_{\mathrm{x}}$ is density of magmatic underplating material.

The range of parameters and the estimates of underplating-derived denudation $\left(D_{X}\right)$ are given in Table 4 . At most sites $\mathrm{D}_{\mathrm{X}}$ is significantly lower than the total early Paleogene denudation predicted by the thermal histories $\left(D_{\text {total }}\right)$. This implies that the emplacement of the underplating layer is insufficient to account for the total denudation. The 'missing' portion of denudation $\left(\mathrm{D}_{\text {total- } \mathrm{X}}\right)$ is, however, relatively constant across the region $(802 \pm 266$ $\mathrm{m})$ and requires a further source of rock uplift. In contrast, in north Wales, the calculated amount of denudation driven by underplating exceeds the predicted denudation, for a range of possible parameters and the thickness of the underplating rock (Al-Kindi et al., 2003; Tomlinson et al., 2006). This may result from overestimates of the thickness of early Cenozoic underplating; the crustal section of north Wales is the oldest of the three study regions and may record previous underplating events.

4.4 Transient plume-related uplift

The spatial uniformity of the missing portion of denudation requires that the uplift that initiated erosion also had limited spatial variability. The thermal histories indicate that the onset of cooling predated the magmatic activity. The first phase of uplift may be, therefore, related to the dynamic and thermal support from the mantle plume. Assuming local isostasy, the amount of thermal-dynamic, plume-related uplift $\left(\mathrm{U}_{t}\right)$ necessary to explain the non-underplating driven denudation can be calculated as follows (Braun et al., 2006; Fig. S6b):

$U_{t}=U_{r}-I=h_{i}-h_{0}+D\left(1-\frac{\rho_{s}}{\rho_{m}}\right)$

where $U_{t}$ is transient, plume-related uplift, $U_{r}$ is rock uplift, $I$ is isostatic rebound, $h_{i}$ is present-day surface elevation, $\mathrm{h}_{0}$ is initial surface elevation, $\mathrm{D}$ is denudation, $\rho_{\mathrm{s}}$ is density of eroded material, and $\rho_{\mathrm{m}}$ is density of asthenosphere/mantle.

Equation (2) assumes that $h_{0}$ is above sea level, whereas in our case the uplift started when the region was flooded by the Late Cretaceous sea. We can show that $h_{i}=T$ and $h_{0}=-$ $\mathrm{W}$ if we account for the effect of water density (Fig. S6c). After transforming equation (2) to calculate denudation we obtain:

$$
D=\left(\frac{\rho_{m}}{\rho_{m}-\rho_{s}}\right) U_{t}-\left(\frac{\rho_{m}}{\rho_{m}-\rho_{s}}\right) T-\left(\frac{\rho_{m}-\rho_{w}}{\rho_{m}-\rho_{s}}\right) W
$$

Assuming that each uplift component contributes to the net change in elevation (Fig. S7), we can show that: 


$$
D_{\text {total }}=\left(\frac{\rho_{m}}{\rho_{m}-\rho_{s}}\right) U_{t}-\left(\frac{\rho_{m}}{\rho_{m}-\rho_{s}}\right) T_{t}-\left(\frac{\rho_{m}-\rho_{w}}{\rho_{m}-\rho_{s}}\right) W+\left(\frac{\rho_{m}-\rho_{x}}{\rho_{m}-\rho_{s}}\right) X-\left(\frac{\rho_{m}}{\rho_{m}-\rho_{s}}\right) T_{p d}+\left(\frac{\rho_{m}}{\rho_{m}-\rho_{s}}\right) T_{t}
$$

where: $\mathrm{D}_{\text {total }}$ is total denudation, inferred from thermochronometric data, $\mathrm{T}_{t}$ is topography created by thermal-dynamic uplift and $\mathrm{T}_{\mathrm{pd}}$ is present-day topography. As the elements of the equation (4) containing $T_{t}$ will be reduced, we can show that total denudation is equal to:

$$
D_{\text {total }}=\left(\frac{\rho_{m}}{\rho_{m}-\rho_{s}}\right) U_{t}+\left(\frac{\rho_{m}-\rho_{x}}{\rho_{m}-\rho_{s}}\right) X-\left(\frac{\rho_{m}}{\rho_{m}-\rho_{s}}\right) T_{p d}-\left(\frac{\rho_{m}-\rho_{w}}{\rho_{m}-\rho_{s}}\right) W
$$

We can transform the equation (5) and calculate amount of thermal-dynamic uplift required to produce the observed total denudation and support the present-day topography:

$$
\boldsymbol{U}_{\boldsymbol{t}}=\left(\frac{\rho_{m}-\rho_{s}}{\rho_{m}}\right) \boldsymbol{D}_{\text {total }}-\left(\frac{\rho_{m}-\rho_{x}}{\rho_{m}}\right) X+T_{p d}+\left(\frac{\rho_{m}-\rho_{w}}{\rho_{m}}\right) W
$$

The density of the eroded material during the $\mathrm{U}_{\mathrm{T}}$ phase is assumed to be $2.0-2.2$ $\mathrm{g} / \mathrm{cm}^{3}$, given that the whole area was covered by sedimentary rocks. For the new calculation that combines both uplift components, we take into account the density change of the basement rocks and we calculate a mean eroded rock density, which is a weighted average of the densities of the basement and sedimentary rocks, based on their share in the total eroded section, as given in Table 3.

The 'missing' portion of denudation translates to $\sim 300 \mathrm{~m}$ of rock uplift (Table 4).

This is similar to values of isostatically balanced residual topography supported by the present-day dynamic support of anomalously hot mantle (Davis et al., 2012). The average $U_{t}$ is consistent with theoretical values calculated considering the effect of density changes due to anomalously hot mantle; numerical models have shown that a mantle temperature increase of $100^{\circ} \mathrm{C}$ can produce $\sim 500 \mathrm{~m}$ uplift (White \& McKenzie, 1989). Likely, the dynamicthermal uplift was higher in the early Paleogene, when it could reach $\geq 500 \mathrm{~m}$. A lower value for the density of the eroded material, more consistent with poorly compacted sediments, would increase $U_{t}$. Similarly, $U_{t}$ increases if the density of the underplating material was higher. In turn, eustatic sea level drop since the Late Cretaceous ( 200 m, Haq, 2014) decreases $U_{t}$ by a value equal to this sea level change (Brown, 1991), which is, however, difficult to constrain and remain under debate.

\section{Discussion}

The timing and spatial distribution of the early Paleogene rock uplift are consistent with a mantle plume origin. That the permanent component of the uplift was driven by underplating has been widely accepted (e.g. Cogné et al., 2016; Tiley et al., 2004; White \& Lovell, 1997), but here we quantify its contribution and we demonstrate that a transient uplift component, likely caused by dynamic support of the upwelling material and/or thermal expansion is necessary to explain the amounts of denudation derived from thermochronometry.

Our calculations assume that the thermal-dynamic support is still present beneath the region. This is consistent with the seismic studies that indicate that, at present, the mantle underlying the British Isles is anomalously hot, providing additional, dynamic support for existing topography, especially in NW Scotland (Arrowsmith et al., 2005; Bott \& Bott, 2004; Davis et al., 2012). If the transient uplift component was totally removed, subsidence would occur with sea transgression. The link between mantle anomalies and topography is also supported by the fact that underneath basins surrounding the British Isles the mantle is not anomalous (Arrowsmith et al., 2005; Bott \& Bott, 2004; Davis et al., 2012). The North Sea, Porcupine and the Faroe-Shetland Basins have estimated Paleocene uplift of 300-500 m, 
300-600 m and 500-900 m, respectively, followed by subsidence in the Eocene (Hartley et al., 2011; Jones et al., 2001; Nadin et al., 1997; Rudge et al., 2008; Shaw Champion et al., 2008). The isostatically balanced residual topography in central west Britain varies from $0 \mathrm{~m}$ in the EISB to $\sim 800 \mathrm{~m}$ in NW Scotland, with values of 200-300 m observed in most of the onshore area, including the Lake District (Davis et al., 2012), similar to the values obtained in this study. Our results are consistent with the hypothesis that the crust beneath western Britain is thermo-dynamically supported.

The data suggest that the uplift initiated at $70 \pm 5 \mathrm{Ma}$ (Maastrichtian), significantly earlier than plume-related volcanism. Uplift in the North Atlantic region related to phase I of the volcanism $(62-59 \mathrm{Ma})$ is likely minor, affecting only the regions around the magmatic centers. The most important regional uplift event is considered to have occurred with phase II of the volcanism ( 56.5-54 Ma) (Saunders et al., 2007). Most of the modeling and seismic data from the basins place the plume-related uplift in the Paleocene-Eocene (Hartley et al., 2011; Nadin et al., 1997; Shaw Champion et al., 2008). Most of the AFT studies from onshore also attribute the onset of uplift and denudation to the early Paleogene, $\sim 60 \mathrm{Ma}$ (Cogné et al., 2016; Green, 1986, 2002; Persano et al., 2007), although other studies indicate a broader time span, e.g. 80-50 Ma (Green, 1989) or $65 \pm 5$ Ma (Lewis et al., 1992).

A rapid uplift pulse in the Maastrichtian has been proposed for East Greenland (Petersen et al., 2015) and Maastrichtian basin inversion has been detected in the Vøring Basin (Lundin et al., 2013). A late Maastrichtian to Paleogene uplift of the British Isles was suggested by Cope (1994), based on analysis of the unconformities and published AFT data. The onset of uplift in the Maastrichtian is also supported by the regional changes of the Late Cretaceous sea, which, after reaching a maximum in the Campanian, was subjected to the final regression in the Maastrichtian (Hancock, 1975, 1989). Numerical modeling of the surface effects of the impingement of the proto-Iceland mantle plume indicates several hundred meters of dynamic topography in the British Isles between 70-50 Ma, with a peak at around $60 \mathrm{Ma}$ (Barnett-Moore et al., 2017).

Latest Cretaceous uplift predates the first volcanism in the North Atlantic Igneous Province by several millions of years; the earliest lavas, the Antrim basalts in NE Ireland, were erupted at $62.6 \pm 0.3 \mathrm{Ma}$ (Ganerød et al., 2010). The evidence of uplift-erosion prior to the volcanism is widespread in NW Scotland and Northern Ireland, where subaerial Paleocene lavas lie unconformably on Jurassic or Cretaceous rocks (Brown et al., 2009; Hopson, 2005; Simms, 2000; Williamson \& Bell, 2012). The common feature is a clearly erosional unconformity between the brecciated Mesozoic rocks and Paleocene lavas (Williamson \& Bell 2012). In Northern Ireland, Paleocene lavas (62.6-59.6 Ma) (Ganerød et al., 2010) are underlain by early Maastrichtian chalk (70-72 Ma) (Simms, 2000) exhibiting significant karstic erosion that implies uplift-erosion between $\sim 70 \mathrm{Ma}$ and $62.6 \mathrm{Ma}$.

The latest Cretaceous denudation is not well recorded offshore, as sedimentation rate of siliciclastics at that time in the Faroe-Shetland, Porcupine and North Sea Basins was low, compared to later Cenozoic phases (Liu \& Galloway, 1997; Mudge, 2015; Stoker et al., 2010). However, Late Cretaceous chalk probably made up a large component of the rock that was eroded. This would have been removed in solution and may not have made a significant contribution to the offshore successions (Cope, 1994; Simms, 2004).

Several studies have argued that Cenozoic denudation was episodic, including a major post-Paleocene component, due to complex intra-plate stress generated by plate reorganization (Hillis et al., 2008; Holford et al., 2005; Japsen et al., 2012; Stoker et al., 2010). The spatial distribution of denudation identified by this study does not support the compressional nature of the uplift. There is no evidence for the reactivation of old structures, 
the uplift had a regional character and the geographical distribution of denudation has a smooth, long wavelength character. Cenozoic compressional structures are observed mostly in south England (Blundell, 2002; Hillis et al., 2008), their number and magnitude decrease northwards (Ziegler 1990); finally the observed amounts of denudation are more than ten times larger than expected for the amount of total shortening observed in the region (White et al., 2013). Therefore, although the compressional intra-plate stress likely played an important role in exhumation of south England, its impact in the central west Britain seems to have been minor, if any.

Westaway (2009, 2017) and Green et al. (2012) have suggested that Neogene exhumation was significant, driven by lower-crustal flow due to rapid subsidence and deposition in the North Sea. Our study provides little clear evidence for a resolvable regional Late Cenozoic cooling. Cooling equivalent to $\sim 1 \mathrm{~km}$ in the last few million years is suggested only by a few models from SW Scotland (e.g. Corsewall Point), but the event is poorly resolved, as in most of the area its magnitude is well below the sensitivity of the low temperature thermochronometers. The spatial distribution of the possible NeogeneQuaternary uplift does not match the area in northern England supposedly affected by lowercrustal flow (Green et al., 2012; Westaway, 2017). A pulse of erosion in W Scotland in the Quaternary can be better explained by a post-glacial isostatic rebound (Shennan \& Horton, 2002) given that the present-day dynamic support from the anomalously hot mantle is the highest here (Davis et al., 2012).

\section{Conclusions}

Combining AHe, ZHe, and AFT data from central west Britain has allowed thermal histories to be more precisely resolved. Denudation appears to start in the latest Cretaceous ( $70 \mathrm{Ma})$, peaking in the Paleocene and ceasing by $\sim 40 \mathrm{Ma}$. Rock uplift preceded magmatism by a few million years, in agreement with the presence of an erosional unconformity beneath the Paleocene lavas. Between 1.0 and $2.4 \mathrm{~km}$ of rock was eroded. Most was remoyed in the northern EISB and south coast of Scotland, reflecting the thickness of magmatic underplated material. Underplating-related uplift is, however, insufficient to account for all the denudation. At least $300 \mathrm{~m}$ of transient thermal-dynamic uplift is required to account for the 'missing portion' of denudation. By accounting for the heterogeneities in rock thermal properties, rock density and topography, transient and permanent components of mantle plume-related uplift causes can be apportioned.

Our results suggest that the total denudation in central west Britain in the latest Cretaceous-early Paleogene can be attributed to the processes related to the arrival of the proto-Iceland mantle plume. The spatial distribution of denudation is unrelated to crustal structures, ruling out significant intra-plate stresses that would have reactivated pre-existing tectonic structures. Our data refute the hypothesis that the main denudation occurred in the Neogene due to lower crustal flow, although there may have been a Quaternary cooling episode in SW Scotland, where the hot mantle may have favored post-glacial-driven isostatic rebound.

\section{Acknowledgments}

Full analytical details, data tables, and QTQt models are available in the text and in the Supporting Information. We thank Kerry Gallagher for providing the code used for the 1D thermal modeling. This work was funded by the University of Glasgow and SUERC. Nathan Cogné, Taylor Schildgen and an anonymous reviewer are thanked for their constructive comments. 


\section{References}

Akhurst, M. C. (Eds.). (1997). Geology of the west Cumbria district. Vol. 28, British Geological Survey.

Al-Kindi, S., White, N., Sinha, M., England, R., \& Tiley, R. (2003). Crustal trace of a hot convective sheet. Geology, 31(3), 207-210. doi: 10.1130/0091-

7613(2003)031<0207:CTOAHC > 2.0.CO;2

Arrowsmith, S. J., Kendall, M., White, N., VanDecar, J. C., \& Booth, D. C. (2005). Seismic imaging of a hot upwelling beneath the British Isles. Geology, 33(5), 345-348. doi: $10.1130 / \mathrm{G} 21209.1$

Bamford, D., Nunn, K., Prodehl, C., \& Jacob, B. (1978). LISPB-IV. Crustal structure of northern Britain. Geophysical Journal International, 54(1), 43-60. doi: 10.1111/j.1365246X.1978.tb06755.X

Barnett-Moore, N., Hassan, R., Flament, N., \& Müller, D. (2017). The deep Earth origin of the Iceland plume and its effects on regional surface uplift and subsidence. Solid Earth, 8(1), 235. doi: $10.5194 / \mathrm{se}-8-235-2017$

Beucher, R., Brown, R. W., Roper, S., Stuart, F., \& Persano, C. (2013). Natural age dispersion arising from the analysis of broken crystals: Part II. Practical application to apatite (U-Th)/He thermochronometry. Geochimica et Cosmochimica Acta, 120, 395-416. doi: 10.1016/j.gca.2013.05.042

Bluck, B. J., Dempster, T. J., Aftalion, M., Haughton, P. D. W., \& Rogers, G. (2006). Geochronology of a granitoid boulder from the Corsewall Formation (Southern Uplands): implications for the evolution of southern Scotland. Scottish Journal of Geology, 42(1), 2935. doi: $10.1144 / \mathrm{sjg} 42010029$

Bott, M. H. (1974). The geological interpretation of a gravity survey of the English Lake District and the Vale of Eden. Journal of the Geological Society, 130(4), 309-328. doi: 10.1144/gsjgs.130.4.0309

Bott, M. H., \& Bott, J. D. (2004). The Cenozoic uplift and earthquake belt of mainland Britain as a response to an underlying hot, low-density upper mantle. Journal of the Geological Society, 161(1), 19-29. doi: 10.1144/0016-764903-014

Bott, M. H. P., Long, R. E., Green, A. S. P., Lewis, A. H. J., Sinha, M. C., \& Stevenson, D. L. (1985). Crustal structure south of the Iapetus suture beneath northern England. Nature, 314(6013), 724-727. doi: 10.1038/314724a0

Braun, J. (2010). The many surface expressions of mantle dynamics. Nature Geoscience, 3(12), 825. doi: 10.1038/ngeo1020

Braun, J., Van Der Beek, P., \& Batt, G. (2006). Quantitative thermochronology: numerical methods for the interpretation of thermochronological data. Cambridge University Press. pp. 270.

Braun, J., Simon-Labric, T., Murray, K. E., \& Reiners, P. W. (2014). Topographic relief driven by variations in surface rock density. Nature Geoscience, 7(7), 534. doi: 10.1038/ngeo2171

Brown, R. W. (1991). Backstacking apatite fission-track" stratigraphy": A method for resolving the erosional and isostatic rebound components of tectonic uplift histories. Geology, 19(1), 74-77. doi: 10.1130/0091-7613(1991)019<0074:BAFTSA>2.3.CO;2

Brown, D. J., Holohan, E. P., \& Bell, B. R. (2009). Sedimentary and volcano-tectonic 
processes in the British Paleocene Igneous Province: a review. Geological Magazine, 146(3), 326-352. doi: 10.1017/S0016756809006232

Brown, P. E., Miller, J. A., \& Grasty, R. L. (1968, February). Isotopic ages of late Caledonian granitic intrusions in the British Isles. In Proceedings of the Yorkshire Geological and Polytechnic Society (Vol. 36, No. 3, pp. 251-276). Geological Society of London. doi: 10.1144/pygs.36.3.251

Brown, R., Gallagher, K., \& Duane, M. (1994). A quantitative assessment of the effects of magmatism on the thermal history of the Karoo sedimentary sequence. Journal of African Earth Sciences, 18(3), 227-243. doi: 10.1016/0899-5362(94)90007-8

Brown, R. W., Beucher, R., Roper, S., Persano, C., Stuart, F., \& Fitzgerald, P. (2013).

Natural age dispersion arising from the analysis of broken crystals. Part I: Theoretical basis and implications for the apatite (U-Th)/He thermochronometer. Geochimica et Cosmochimica Acta, 122, 478-497. doi: 10.1016/j.gca.2013.05.041

Chadwick, R. A., Kirby, G. A., \& Baily, H. E. (1994, October). The post-Triassic structural evolution of north-west England and adjacent parts of the East Irish Sea. In Proceedings of the Yorkshire Geological and Polytechnic Society (Vol. 50, No. 1, pp. 91-102). Geological Society of London. doi: 10.1144/pygs.50.1.91

Cogné, N., Chew, D., \& Stuart, F. M. (2014). The thermal history of the western Irish onshore. Journal of the Geological Society, 171(6), 779-792. doi: 10.1144/jgs2014-026

Cogné, N., Doepke, D., Chew, D., Stuart, F. M., \& Mark, C. (2016). Measuring plumerelated exhumation of the British Isles in Early Cenozoic times. Earth and Planetary Science Letters, 456, 1-15. doi: 10.1016/j.eps1.2016.09.053

Cope, J. C. W. (1994). A latest Cretaceous hotspot and the southeasterly tilt of Britain. Journal of the Geological Society, 151(6), 905-908. doi: 10.1144/gsjgs.151.6.0905

Cox, K. G. (1993). Continental magmatic underplating. Philosophical Transactions: Physical Sciences and Engineering, 342(1663), 155-166. doi: 10.1098/rsta.1993.0011

Croudace, I. W. (1982). The geochemistry and petrogenesis of the lower Paleozoic granitoids of the Lleyn Peninsula, North Wales. Geochimica et Cosmochimica Acta, 46(4), 609-621. doi: 10.1016/0016-7037(82)90162-4

Davis, M. W., White, N. J., Priestley, K. F., Baptie, B. J., \& Tilmann, F. J. (2012). Crustal structure of the British Isles and its epeirogenic consequences. Geophysical Journal International, 190(2), 705-725. doi: 10.1111/j.1365-246X.2012.05485.x

Dobson, K. J., Stuart, F. M., \& Dempster, T. J. (2008). U and Th zonation in Fish Canyon Tuff zircons: implications for a zircon (U-Th)/He standard. Geochimica et Cosmochimica Acta, 72(19), 4745-4755. doi: 10.1016/j.gca.2008.07.015

Downing, R. A., \& Gray, D. A. (1986). Geothermal resources of the United Kingdom. Journal of the Geological Society, 143(3), 499-507. doi: 10.1144/gsjgs.143.3.0499

Farley, K. A. (2002). (U-Th)/He dating: Techniques, calibrations, and applications. Reviews in Mineralogy and Geochemistry, 47(1), 819-844. doi: 10.2138/rmg.2002.47.18

Farrell, T., Muller, M., Rath, V., Feely, M., Jones, A., \& Brock, A. (2015). IRETHERM: The Geothermal Energy Potential of Radiothermal Granites in a Low-Enthalpy Setting in Ireland from Magnetotelluric Data. Paper presented at Proceedings World Geothermal Congress, Melbourne, Australia.

Gallagher, K. (2012). Transdimensional inverse thermal history modeling for quantitative 
thermochronology. Journal of Geophysical Research: Solid Earth, 117(B2). doi: 10.1029/2011JB008825

Gallagher, K. (2017). QTQt v 5.6.0 User Guide. January 2017, 1-76.

Ganerød, M., Smethurst, M. A., Torsvik, T. H., Prestvik, T., Rousse, S., McKenna, C., ... \& Hendriks, B. W. H. (2010). The North Atlantic Igneous Province reconstructed and its relation to the plume generation zone: the Antrim Lava Group revisited. Geophysical Journal International, 182(1), 183-202. doi: 10.1111/j.1365-246X.2010.04620.x

Gautheron, C., \& Tassan-Got, L. (2010). A Monte Carlo approach to diffusion applied to noble gas/helium thermochronology. Chemical Geology, 273(3), 212-224. doi:

10.1016/j.chemgeo.2010.02.023

Gautheron, C., Tassan-Got, L., Barbarand, J., \& Pagel, M. (2009). Effect of alpha-damage annealing on apatite (U-Th)/He thermochronology. Chemical Geology, 266(3), 157-170. doi: 10.1016/j.chemgeo.2009.06.001

Gautheron, C., Tassan-Got, L., Ketcham, R. A., \& Dobson, K. J. (2012). Accounting for long alpha-particle stopping distances in (U-Th-Sm)/He geochronology: 3D modeling of diffusion, zoning, implantation, and abrasion. Geochimica et Cosmochimica Acta, 96, 44-56. doi: $10.1016 /$ j.gca.2012.08.016

Gautheron, C., Barbarand, J., Ketcham, R. A., Tassan-Got, L., van der Beek, P., Pagel, M., ... $\&$ Fialin, M. (2013). Chemical influence on $\alpha$-recoil damage annealing in apatite:

Implications for (U-Th)/He dating. Chemical Geology, 351, 257-267. doi:

10.1016/j.chemgeo.2013.05.027

Gleadow, A. J. W., \& Duddy, I. R. (1981). A natural long-term track annealing experiment for apatite. Nuclear Tracks, 5(1-2), 169-174. doi: 10.1016/0191-278X(81)90039-1

Green, P. F. (1986). On the thermo-tectonic evolution of Northern England: evidence from fission track analysis. Geological Magazine, 123(5), 493-506. doi: $10.1017 /$ S0016756800035081

Green, P. F. (1989). Thermal and tectonic history of the East Midlands shelf (onshore UK) and surrounding regions assessed by apatite fission track analysis. Journal of the Geological Society, 146(5), 755-773. doi: 10.1144/gsjgs.146.5.0755

Green, P. F. (2002). Early Tertiary paleo-thermal effects in Northern England: reconciling results from apatite fission track analysis with geological evidence. Tectonophysics, 349(1), 131-144. doi: 10.1016/S0040-1951(02)00050-1

Green, P. F., Duddy, I. R., \& Bray, R. J. (1997). Variation in thermal history styles around the Irish Sea and adjacent areas: implications for hydrocarbon occurrence and tectonic evolution. Geological Society, London, Special Publications, 124(1), 73-93. doi: 10.1144/GSL.SP.1997.124.01.06

Green, P. F., Westaway, R., Manning, D. A. C., \& Younger, P. L. (2012). Cenozoic cooling and denudation in the North Pennines (northern England, UK) constrained by apatite fissiontrack analysis of cuttings from the Eastgate Borehole. Proceedings of the Geologists' Association, 123(3), 450-463. doi: 10.1016/j.pgeola.2011.11.003

Guenthner, W. R., Reiners, P. W., Ketcham, R. A., Nasdala, L., \& Giester, G. (2013). Helium diffusion in natural zircon: Radiation damage, anisotropy, and the interpretation of zircon (UTh)/He thermochronology. American Journal of Science, 313(3), 145-198. doi:

10.2475/03.2013.01 
Hancock, J. M. (1975). The petrology of the Chalk. Proceedings of the Geologists' Association, 86(4), 499-535. doi: 10.1016/S0016-7878(75)80061-7

Hancock, J. M. (1989). Sea-level changes in the British region during the Late Cretaceous. Proceedings of the Geologists' Association, 100(4), 565IN1-594. doi: 10.1016/S00167878(89)80027-6

Hartley, R, A., Roberts, G. G., White, N., \& Richardson, C. (2011). Transient convective uplift of an ancient buried landscape. Nature Geoscience, 4(8), 562. doi: 10.1038/ngeo1191

Haq, B. U. (2014). Cretaceous eustasy revisited. Global and Planetary Change, 113, 44-58. doi: 10.1016/j.gloplacha.2013.12.007

Hillis, R. R., Holford, S. P., Green, P. F., Doré, A. G., Gatliff, R. W., Stoker, M. S., ... \& Williams, G. A. (2008). Cenozoic exhumation of the southern British Isles. Geology, 36(5), 371-374. doi: 10.1130/G24699A.1

Hobbs, P., Hallam, J. R., Forster, A., Entwisle, D., Jones, L. D., Cripps, A. C., ... \& Meakin, J. L. (2002). Engineering geology of British rocks and soils: Mudstones of the Mercia Mudstone Group. pp. 106, British Geological Survey Report RR/01/002.

Holford, S. P., Turner, J. P., \& Green, P. F. (2005, January). Reconstructing the MesozoicCenozoic exhumation history of the Irish Sea basin system using apatite fission track analysis and vitrinite reflectance data. In Geological Society, London, Petroleum Geology Conference series (Vol. 6, No. 1, pp. 1095-1107). Geological Society of London. doi: 10.1144/0061095

Holliday, D. W. (1993). Mesozoic cover over northern England: interpretation of apatite fission track data. Journal of the Geological Society, 150(4), 657-660. doi:

10.1144/gsjgs.150.4.0657

Hopson, P. (2005). A stratigraphical framework for the Upper Cretaceous Chalk of England and Scotland with statements on the Chalk of Northern Ireland and the UK Offshore Sector. British Geological Survey.

Jackson, D. I., \& Mulholland, P. (1993). Tectonic and stratigraphic aspects of the East Irish Sea Basin and adjacent areas: contrasts in their post-Carboniferous structural styles. In Geological Society, London, Petroleum Geology Conference series (Vol. 4, No. 1, pp. 791808). Geological Society of London. doi: 10.1144/0040791

Japsen, P., Chalmers, J. A., Green, P. F., \& Bonow, J. M. (2012). Elevated, passive continental margins: Not rift shoulders, but expressions of episodic, post-rift burial and exhumation. Global and Planetary Change, 90, 73-86. doi: 10.1016/j.gloplacha.2011.05.004

Jones, S. M., White, N., \& Lovell, B. (2001). Cenozoic and Cretaceous transient uplift in the Porcupine Basin and its relationship to a mantle plume. Geological Society, London, Special Publications, 188(1), 345-360. doi: 10.1144/GSL.SP.2001.188.01.20

Jones, S. M., White, N., Clarke, B. J., Rowley, E., \& Gallagher, K. (2002). Present and past influence of the Iceland Plume on sedimentation. Geological Society, London, Special Publications, 196(1), 13-25. doi: 10.1144/GSL.SP.2002.196.01.02

Ketcham, R. A., Carter, A., Donelick, R. A., Barbarand, J., \& Hurford, A. J. (2007). Improved modeling of fission-track annealing in apatite. American Mineralogist, 92(5-6), 799-810. doi: 10.2138/am.2007.2281

Lewis, C. L., Green, P. F., Carter, A., \& Hurford, A. J. (1992). Elevated K/T palaeotemperatures throughout Nortwest England: three kilometres of Tertiary erosion?. Earth and Planetary Science Letters, 112(1-4), 131-145. doi: 10.1016/0012-821X(92)90012- 
Lister, G. S., Etheridge, M. A., \& Symonds, P. A. (1991). Detachment models for the formation of passive continental margins. Tectonics, 10(5), 1038-1064. doi: 10.1029/90TC01007

Liu, X., \& Galloway, W. E. (1997). Quantitative determination of Tertiary sediment supply to the North Sea Basin. AAPG bulletin, 81(9), 1482-1509.

Lundin, E. R., Doré, A. G., Rønning, K., \& Kyrkjebø, R. (2013). Repeated inversion and collapse in the Late Cretaceous-Cenozoic northern Vøring Basin, offshore Norway.

Petroleum Geoscience, 19(4), 329-341. doi: 10.1144/petgeo2012-022

Łuszczak, K., Persano, C., Braun, J., \& Stuart, F. M. (2017). How local crustal thermal properties influence the amount of denudation derived from low-temperature thermochronometry. Geology, 45(9), 779-782. doi: 10.1130/G39036.1

Mackay, L. M., \& White, N. J. (2006). Accurate estimates of the spatial pattern of denudation by inversion of stacking velocity data: An example from the British Isles. Geochemistry, Geophysics, Geosystems, 7(10). doi: 10.1029/2005GC001192

Maclennan, J., \& Lovell, B. (2002). Control of regional sea level by surface uplift and subsidence caused by magmatic underplating of Earth's crust. Geology, 30(8), 675-678. doi: 10.1130/0091-7613(2002)030<0675:CORSLB>2.0.CO;2

McDowell, F. W., McIntosh, W. C., \& Farley, K. A. (2005). A precise 40 Ar-39 Ar reference age for the Durango apatite (U-Th)/He and fission-track dating standard. Chemical Geology, 214(3), 249-263. doi: 10.1016/j.chemgeo.2004.10.002

Meesters, A. G. C. A., \& Dunai, T. J. (2005). A noniterative solution of the (U-Th)/He age equation. Geochemistry, Geophysics, Geosystems, 6(4). doi: 10.1029/2004GC000834

Montgomery, D. R., \& Brandon, M. T. (2002). Topographic controls on erosion rates in tectonically active mountain ranges. Earth and Planetary Science Letters, 201(3), 481-489. doi: $10.1016 / \mathrm{S} 0012-821 \mathrm{X}(02) 00725-2$

Moucha, R., \& Forte, A. M. (2011). Changes in African topography driven by mantle convection. Nature Geoscience, 4(10), 707-712. doi: 10.1038/ngeo1235

Mudge, D. C. (2015). Regional controls on Lower Tertiary sandstone distribution in the North Sea and NE Atlantic margin basins. Geological Society, London, Special Publications, 403(1), 17-42. doi: 10.1144/SP403.5

Murray, K. E., Orme, D. A., \& Reiners, P. W. (2014). Effects of U-Th-rich grain boundary phases on apatite helium ages. Chemical Geology, 390, 135-151. doi:

10.1016/j.chemgeo.2014.09.023

Nadin, P. A., Kusznir, N. J., \& Cheadle, M. J. (1997). Early Tertiary plume uplift of the North Sea and Faeroe-Shetland basins. Earth and Planetary Science Letters, 148(1-2), 109127. doi: 10.1016/S0012-821X(97)00035-6

Persano, C., Stuart, F. M., Bishop, P., \& Barfod, D. N. (2002). Apatite (U-Th)/He age constraints on the development of the Great Escarpment on the southeastern Australian passive margin. Earth and Planetary Science Letters, 200(1), 79-90. doi: 10.1016/S0012$821 \mathrm{X}(02) 00614-3$

Persano, C., Barfod, D. N., Stuart, F. M., \& Bishop, P. (2007). Constraints on early Cenozoic underplating-driven uplift and denudation of western Scotland from low temperature 
thermochronometry. Earth and Planetary Science Letters, 263(3), 404-419. doi: 10.1016/j.eps1.2007.09.016

Petersen, T. G., Hamann, N. E., \& Stemmerik, L. (2015). Tectono-sedimentary evolution of the Paleogene succession offshore Northeast Greenland. Marine and Petroleum Geology, 67, 481-497. doi: 10.1016/j.marpetgeo.2015.05.033

Reiners, P. W., Farley, K. A., \& Hickes, H. J. (2002). He diffusion and (U-Th)/He thermochronometry of zircon: initial results from Fish Canyon Tuff and Gold Butte. Tectonophysics, 349(1), 297-308. doi: 10.1016/S0040-1951(02)00058-6

Rowley, E., \& White, N. (1998). Inverse modelling of extension and denudation in the East Irish Sea and surrounding areas. Earth and Planetary Science Letters, 161(1), 57-71. doi: 1016/S0012-821X(98)00137-X

Rudge, J. F., Shaw Champion, M. E. S., White, N., McKenzie, D., \& Lovell, B. (2008). A plume model of transient diachronous uplift at the Earth's surface. Earth and Planetary Science Letters, 267(1), 146-160. doi: 10.1016/j.epsl.2007.11.040

Rundle, C. C. (1979). Ordovician intrusions in the English Lake District. Journal of the Geological Society, 136(1), 29-38. doi: 10.1144/gsjgs.136.1.0029

Saunders, A. D., Jones, S. M., Morgan, L. A., Pierce, K., Widdowson, M., \& Xu, Y. G. (2007). Regional uplift associated with continental large igneous provinces: the roles of mantle plumes and the lithosphere. Chemical Geology, 241(3), 282-318. doi:

10.1016/j.chemgeo.2007.01.017

Shaw Champion, M. E., White, N. J., Jones, S. M., \& Lovell, J. P. B. (2008). Quantifying transient mantle convective uplift: An example from the Faroe-Shetland basin. Tectonics, 27(1). doi: 10.1029/2007TC002106

Shennan, I., \& Horton, B. (2002). Holocene land-and sea-level changes in Great Britain. Journal of Quaternary science, 17(5-6), 511-526. doi: 10.1002/jqs.710

Simms, M. J. (2000). The sub-basaltic surface in northeast Ireland and its significance for interpreting the Tertiary history of the region. Proceedings of the Geologists' Association, 111(4), 321-336. doi: 10.1016/S0016-7878(00)80088-7

Simms, M. J. (2004). Tortoises and hares: Dissolution, erosion and isostasy in landscape evolution. Earth Surface Processes and Landforms, 29(4), 477-494. doi: 10.1002/esp.1047

Stephenson, D. (2003). Carboniferous and Permian igneous rocks of Great Britain, north of the Variscan Front (Vol. 27). Joint Nature Conservation Committee.

Stoker, M. S., Holford, S. P., Hillis, R. R., Green, P. F., \& Duddy, I. R. (2010). Cenozoic post-rift sedimentation off northwest Britain: Recording the detritus of episodic uplift on a passive continental margin. Geology, 38(7), 595-598. doi: 10.1130/G30881.1

Stuart, F. M., Ellam, R. M., Harrop, P. J., Fitton, J. G., \& Bell, B. R. (2000). Constraints on mantle plumes from the helium isotopic composition of basalts from the British Tertiary Igneous Province. Earth and Planetary Science Letters, 177(3), 273-285. doi: 10.1016/S0012-821X(00)00050-9

Tiley, R., McKenzie, D., \& White, N. (2003). The elastic thickness of the British Isles. Journal of the Geological Society, 160(4), 499-502. doi: 10.1144/0016-764902-147

Tiley, R., White, N., \& Al-Kindi, S. (2004). Linking Paleogene denudation and magmatic underplating beneath the British Isles. Geological Magazine, 141(3), 345-351. doi: 


\section{$10.1017 / \mathrm{S} 0016756804009197$}

Tomlinson, J. P., Denton, P., Maguire, P. K. H., \& Booth, D. C. (2006). Analysis of the crustal velocity structure of the British Isles using teleseismic receiver functions. Geophysical Journal International, 167(1), 223-237. doi: 10.1111/j.1365-246X.2006.03044.x

Vernon, A. J., Van Der Beek, P. A., Sinclair, H. D., \& Rahn, M. K. (2008). Increase in late Neogene denudation of the European Alps confirmed by analysis of a fission-track thermochronology database. Earth and Planetary Science Letters, 270(3), 316-329. doi: 10.1016/j.epsl.2008.03.053

Ware, P. D., \& Turner, J. P. (2002). Sonic velocity analysis of the Tertiary denudation of the Irish Sea basin. Geological Society, London, Special Publications, 196(1), 355-370. doi: 10.1144/GSL.SP.2002.196.01.19

Westaway, R. (2009). Quaternary uplift of northern England. Global and Planetary Change, 68(4), 357-382. doi: 10.1016/j.gloplacha.2009.03.005

Westaway, R. (2010). Cenozoic uplift of southwest England. Journal of Quaternary Science, 25(4), 419-432. doi: 10.1002/jqs.1394

Westaway, R. (2017). Isostatic compensation of Quaternary vertical crustal motions: coupling between uplift of Britain and subsidence beneath the North Sea. Journal of Quaternary Science, 32(2), 169-182. doi: 10.1002/jqs.2832

Williamson, I. T., \& Bell, B. R. (2012). The Staffa Lava Formation: graben-related volcanism, associated sedimentation and landscape character during the early development of the Palaeogene Mull Lava Field, NW Scotland. Scottish Journal of Geology, 48(1), 1-46. doi: $10.1144 / 0036-9276 / 01-439$

White, N., \& Lovell, B. (1997). Measuring the pulse of a plume with the sedimentary record. Nature, 387(6636), 888. doi: 10.1038/43151

White, R., \& McKenzie, D. (1989). Magmatism at rift zones: the generation of volcanic continental margins and flood basalts. Journal of Geophysical Research: Solid Earth, 94(B6), 7685-7729. doi: 10.1029/JB094iB06p07685

Ziegler, P. A. (1988). Evolution of the Arctic-North Atlantic and the Western Tethys: A visual presentation of a series of Paleogeographic-Paleotectonic maps. AAPG memoir, 43, 164-196. doi: 10.1306/M43478 
Table 1. Apatite (U-Th-Sm)/He data ${ }^{\mathrm{a}}$.

\begin{tabular}{|c|c|c|c|c|c|c|c|c|c|c|c|c|c|c|c|c|c|}
\hline & No & $\begin{array}{c}\mathrm{L} \\
(\mu \mathrm{m})\end{array}$ & $\begin{array}{l}\text { W1 } \\
(\mu \mathrm{m})\end{array}$ & $\begin{array}{c}\text { W2 } \\
(\mu \mathrm{m})\end{array}$ & $\begin{array}{c}R^{*} \\
(\mu \mathrm{m})\end{array}$ & $\mathrm{T}$ & $\begin{array}{c}\mathrm{He} \\
(\mu \mathrm{cc} / \mathrm{g})\end{array}$ & $\begin{array}{c}U \\
(\mathrm{ppm})\end{array}$ & $\begin{array}{c}\text { Th } \\
\text { (ppm) }\end{array}$ & $\begin{array}{c}\text { Sm } \\
(\mathrm{ppm})\end{array}$ & $\mathrm{Th} / \mathrm{U}$ & $\begin{array}{c}\mathrm{eU} \\
(\mathrm{ppm})\end{array}$ & $\begin{array}{r}\operatorname{age}_{u c} \\
\quad(\mathrm{Ma} \\
\end{array}$ & $1 \sigma^{*}$ & $\mathrm{Ft}$ & $\begin{array}{r}\operatorname{age}_{\mathrm{c}} \\
\quad(\mathrm{Ma})\end{array}$ & $1 \sigma$ \\
\hline \multicolumn{18}{|c|}{ Lake District } \\
\hline \multirow[t]{10}{*}{ LD01 } & 1 & 173 & 122 & 99 & 60 & 0 & 217.8 & 29.1 & 39.4 & 198.4 & 1.4 & 38.3 & 46.5 & 3.7 & 0.8 & 57.1 & 4.6 \\
\hline & 2 & 130 & 128 & 99 & 57 & 1 & 68.3 & 20.9 & 32.4 & 127.4 & 1.6 & 28.5 & 19.7 & 1.6 & 0.8 & 25.0 & 2.0 \\
\hline & 3 & 167 & 121 & 86 & 56 & 1 & 116.0 & 21.8 & 37.9 & 148.2 & 1.7 & 30.7 & 30.9 & 2.5 & 0.8 & 39.9 & 3.2 \\
\hline & 4 & 100 & 120 & 87 & 49 & 0 & 118.6 & 25.9 & 33.1 & 96.5 & 1.3 & 33.7 & 28.9 & 2.3 & 0.8 & 36.1 & 2.9 \\
\hline & 5 & 191 & 118 & 110 & 62 & 1 & 159.0 & 25.7 & 32.7 & 102.5 & 1.3 & 33.4 & 39.1 & 3.1 & 0.8 & 49.2 & 3.9 \\
\hline & 6 & 83 & 178 & 126 & 58 & 1 & 154.3 & 17.5 & 73.6 & 89.8 & 4.2 & 34.8 & 36.4 & 2.9 & 0.8 & 45.3 & 3.6 \\
\hline & 7 & 230 & 75 & 64 & 43 & 2 & 190.9 & 16.2 & 69.7 & 195.6 & 4.3 & 32.5 & 47.9 & 3.8 & 0.7 & 72.1 & 5.8 \\
\hline & 8 & 115 & 184 & 132 & 68 & 1 & 180.1 & 15.1 & 70.1 & 120.9 & 4.6 & 31.6 & 46.6 & 3.7 & 0.8 & 56.6 & 4.5 \\
\hline & 9 & 158 & 122 & 70 & 52 & 1 & 271.5 & 21.5 & 97.8 & 179.1 & 4.6 & 44.5 & 49.9 & 4.0 & 0.7 & 66.9 & 5.4 \\
\hline & 10 & 235 & 94 & 81 & 52 & 2 & 214.0 & 18.8 & 154.9 & 202.4 & 8.3 & 55.2 & 31.7 & 2.5 & 0.7 & 44.4 & 3.5 \\
\hline \multirow[t]{14}{*}{ LD02 } & 1 & 225 & 91 & 72 & 49 & 0 & 12.7 & 3.0 & 4.4 & 198.0 & 1.5 & 4.1 & 24.3 & 1.9 & 0.8 & 32.4 & 2.6 \\
\hline & 2 & 297 & 135 & 116 & 72 & 0 & 15.2 & 2.3 & 3.8 & 168.4 & 1.6 & 3.2 & 36.3 & 2.9 & 0.8 & 43.5 & 3.5 \\
\hline & 3 & 199 & 149 & 153 & 76 & 0 & 19.4 & 3.0 & 5.0 & 142.9 & 1.7 & 4.2 & 36.7 & 2.9 & 0.9 & 42.9 & 3.4 \\
\hline & 4 & 139 & 148 & 136 & 68 & 1 & 27.7 & 4.4 & 8.3 & 167.2 & 1.9 & 6.4 & 34.8 & 2.8 & 0.8 & 42.4 & 3.4 \\
\hline & 5 & 185 & 122 & 100 & 61 & 0 & 14.1 & 1.3 & 5.9 & 117.9 & 4.4 & 2.7 & 40.6 & 3.2 & 0.8 & 50.4 & 4.0 \\
\hline & 6 & 350 & 260 & 156 & 111 & 1 & 32.3 & 3.0 & 8.8 & 175.1 & 2.9 & 5.1 & 49.7 & 4.0 & 0.9 & 56.4 & 4.5 \\
\hline & 7 & 155 & 70 & 61 & 38 & 1 & 26.5 & 3.1 & 12.0 & 96.8 & 3.9 & 5.9 & 36.2 & 2.9 & 0.7 & 55.2 & 4.4 \\
\hline & 8 & 160 & 184 & 131 & 76 & 0 & 19.7 & 1.7 & 6.8 & 122.1 & 4.1 & 3.3 & 47.3 & 3.8 & 0.9 & 54.8 & 4.4 \\
\hline & 9 & 208 & 143 & 111 & 70 & 1 & 29.1 & 2.4 & 10.6 & 134.6 & 4.4 & 4.9 & 47.6 & 3.8 & 0.8 & 58.6 & 4.7 \\
\hline & 10 & 274 & 112 & 130 & 65 & 0 & 22.9 & 1.9 & 7.2 & 231.2 & 3.7 & 3.6 & 48.1 & 3.8 & 0.8 & 59.6 & 4.8 \\
\hline & 11 & 140 & 124 & 97 & 57 & 0 & 37.0 & 4.6 & 17.8 & 190.2 & 3.8 & 8.8 & 33.6 & 2.7 & 0.8 & 41.7 & 3.3 \\
\hline & 12 & 82 & 131 & 112 & 50 & 0 & 18.0 & 1.9 & 9.3 & 189.9 & 4.8 & 4.1 & 34.0 & 2.7 & 0.8 & 41.4 & 3.3 \\
\hline & 13 & 135 & 83 & 66 & 42 & 1 & 19.3 & 0.6 & 8.6 & 127.2 & 13.9 & 2.6 & 56.5 & 4.5 & 0.7 & 83.6 & 6.7 \\
\hline & 14 & 271 & 236 & 112 & 89 & 0 & 22.3 & 2.0 & 7.8 & 230.2 & 3.9 & 3.8 & 44.7 & 3.6 & 0.9 & 51.6 & 4.1 \\
\hline \multirow[t]{5}{*}{ LD12 } & 1 & 126 & 84 & 65 & 39 & 2 & 47.7 & 4.9 & 12.7 & 145.1 & 2.6 & 7.9 & 48.8 & 3.9 & 0.6 & 76.1 & 6.1 \\
\hline & 2 & 113 & 88 & 69 & 42 & 0 & 37.9 & 4.3 & 11.7 & 140.6 & 2.7 & 7.1 & 42.9 & 3.4 & 0.7 & 58.4 & 4.7 \\
\hline & 3 & 147 & 82 & 49 & 37 & 1 & 45.4 & 6.0 & 12.4 & 202.3 & 2.1 & 8.9 & 41.0 & 3.3 & 0.7 & 62.3 & 5.0 \\
\hline & 4 & 113 & 94 & 65 & 39 & 2 & 44.8 & 5.4 & 12.8 & 158.5 & 2.4 & 8.4 & 43.0 & .4 & 0.6 & 67.8 & 5.4 \\
\hline & M1 & 100 & 67 & 58 & 34 & - & 52.9 & 5.8 & 15.8 & 272.0 & 2.7 & 9.5 & 44.1 & 3.5 & 0.6 & 70.5 & 5.6 \\
\hline \multirow[t]{6}{*}{ LD18 } & 1 & 230 & 72 & 68 & 42 & 0 & 53.5 & 7.4 & 7.2 & 238.0 & 1.0 & 9.1 & 46.8 & 3.7 & 0.7 & 66.1 & 5.3 \\
\hline & 2 & 220 & 44 & 40 & 27 & 2 & 267.1 & 27.4 & 110.0 & 241.5 & 4.0 & 53.3 & 41.0 & 3.3 & 0.5 & 84.0 & 6.7 \\
\hline & 3 & 89 & 85 & 83 & 40 & 0 & 368.3 & 18.1 & 115.3 & 203.0 & 6.4 & 45.2 & 66.5 & 5.3 & 0.7 & 90.4 & 7.2 \\
\hline & 4 & 170 & 107 & 95 & 55 & 1 & 255.5 & 16.2 & 18.9 & 480.6 & 1.2 & 20.6 & 41.4 & 3.3 & 0.8 & 53.7 & 4.3 \\
\hline & 5 & 124 & 105 & 100 & 51 & 1 & 252.9 & 40.2 & 54.0 & 159.9 & 1.3 & 52.9 & 39.2 & 3.1 & 0.8 & 51.4 & 4.1 \\
\hline & 6 & 175 & 83 & 69 & 44 & 1 & 454.3 & 39.9 & 243.7 & 36.8 & 6.1 & 97.2 & 38.4 & 3.1 & 0.7 & 55.2 & 4.4 \\
\hline \multicolumn{18}{|c|}{ South Scotland } \\
\hline \multirow[t]{25}{*}{ GAL01 } & & 128 & 89 & 83 & 45 & 1 & 269.3 & 22.1 & 85.6 & 240.0 & 3.9 & 42.2 & 52.0 & 4.2 & 0.7 & 72.5 & 5.8 \\
\hline & 2 & 110 & 89 & 78 & 41 & 1 & 315.2 & 17.3 & 95.8 & 193.0 & 5 & 39.8 & 4.6 & 5.2 & 0.7 & 98.8 & 7.9 \\
\hline & 3 & 135 & 60 & 60 & 34 & 2 & 241.6 & 15.3 & 83.6 & 162.9 & 5.5 & 34.9 & 56.5 & .5 & 0.6 & 98.3 & 7.9 \\
\hline & 4 & 195 & 63 & 55 & 36 & 2 & 261.4 & 20.6 & 107.6 & 227.4 & 5.2 & 45.9 & 46.5 & 3.7 & 0.6 & 76.8 & 6.1 \\
\hline & 5 & 110 & 88 & 77 & 41 & 1 & 285.5 & 21.3 & 74.6 & 225.7 & 3.5 & 38.8 & 60.0 & 4.8 & 0.7 & 91.3 & 7.3 \\
\hline & 6 & 194 & 98 & 84 & 52 & 2 & 387.6 & 44.7 & 59.8 & 177.2 & 1.3 & 58.7 & 54.1 & 4.3 & 0.7 & 73.7 & 5.9 \\
\hline & 7 & 110 & 93 & 71 & 43 & 0 & 246.9 & 17.3 & 52.8 & 244.9 & 3.0 & 29.7 & 67.5 & 5.4 & 0.7 & 90.6 & 7.2 \\
\hline & 8 & 197 & 109 & 94 & 57 & 1 & 612.4 & 41.7 & 53.5 & 242.3 & 1.3 & 54.2 & 92.2 & 7.4 & 0.8 & 118.8 & 9.5 \\
\hline & 9 & 200 & 61 & 52 & 35 & 1 & 217.1 & 38.6 & 68.7 & 221.7 & 1.8 & 54.8 & 32.5 & 2.6 & 0.6 & 52.0 & 4.2 \\
\hline & 10 & 85 & 95 & 81 & 41 & 0 & 413.5 & 49.8 & 75.1 & 202.8 & 1.5 & 67.5 & 50.3 & 4.0 & 0.8 & 65.6 & 5.2 \\
\hline & 11 & 114 & 76 & 65 & 39 & 2 & 225.5 & 26.7 & 64.2 & 204.9 & 2.4 & 41.8 & 44.1 & 3.5 & 0.6 & 69.1 & 5.5 \\
\hline & 12 & 134 & 105 & 88 & 51 & 0 & 127.0 & 13.9 & 36.3 & 225.0 & 2.6 & 22.5 & 45.9 & 3.7 & 0.8 & 58.7 & 4.7 \\
\hline & 13 & 109 & 86 & 82 & 43 & 1 & 599.7 & 71.6 & 92.0 & 295.2 & 1.3 & 93.2 & 52.8 & 4.2 & 0.7 & 73.6 & 5.9 \\
\hline & 14 & 109 & 70 & 65 & 36 & 1 & 529.4 & 70.1 & 72.3 & 206.2 & 1.0 & 87.1 & 49.9 & 4.0 & 0.7 & 75.0 & 6.0 \\
\hline & 15 & 140 & 78 & 67 & 42 & 2 & 633.4 & 72.2 & 92.7 & 269.2 & 1.3 & 93.9 & 55.3 & 4.4 & 0.7 & 83.0 & 6.6 \\
\hline & 16 & 212 & 65 & 56 & 37 & 0 & 387.2 & 39.1 & 62.6 & 255.3 & 1. & 53.8 & 58. & 4.7 & 0.7 & 88.4 & 7.1 \\
\hline & 17 & 95 & 58 & 50 & 30 & 0 & 431.5 & 48.4 & 93.7 & 172.1 & 1.9 & 70.4 & 50. & 4. & 0.6 & 80.4 & 6.4 \\
\hline & 18 & 134 & 100 & 86 & 49 & 1 & 352.1 & 44.5 & 38.8 & 193.7 & 0.9 & 53.7 & 53.8 & 4.3 & 0.8 & 71.6 & 5.7 \\
\hline & 19 & 138 & 135 & 120 & 62 & 1 & 453.6 & 42.8 & 48.9 & 221.8 & 1.1 & 54.3 & 68.3 & 5.5 & 0.8 & 84.4 & 6.8 \\
\hline & 20 & 104 & 104 & 90 & 47 & 1 & 336.6 & 37.2 & 43.1 & 164.7 & 1.2 & 47.4 & 58.2 & 4.7 & 0.8 & 77.6 & 6.2 \\
\hline & 21 & 114 & 105 & 75 & 46 & 1 & 377.0 & 43.7 & 63.2 & 224.1 & 1.4 & 58.6 & 52.7 & 4.2 & 0.7 & 71.4 & 5.7 \\
\hline & 22 & 80 & 85 & 68 & 37 & 0 & 301.4 & 34.7 & 62.1 & 201.4 & 1.8 & 49.3 & 50.1 & 4.0 & 0.7 & 68.4 & 5.5 \\
\hline & 23 & 90 & 114 & 97 & 48 & 0 & 178.0 & 16.9 & 45.8 & 197.9 & 2.7 & 27.7 & 52.4 & 4.2 & 0.8 & 65.6 & 5.2 \\
\hline & 24 & 108 & 159 & 143 & 64 & 0 & 191.4 & 20.1 & 34.1 & 184.1 & 1.7 & 28.1 & 55.6 & 4.4 & 0.9 & 64.6 & 5.2 \\
\hline & & 150 & 125 & 87 & 56 & 1 & 276.7 & 29.4 & 46.1 & 227.0 & 1.6 & 40.2 & 56.2 & 4.5 & 0.8 & 72.0 & 5.8 \\
\hline GAL02 & 1 & 121 & 138 & 122 & 60 & 1 & 425.1 & 19.2 & 87.1 & 254.6 & 4.5 & 39.7 & 87.2 & 7.0 & 0.8 & 109.5 & 8.8 \\
\hline & 2 & 158 & 77 & 63 & 41 & 0 & 194.2 & 13.0 & 40.1 & 412.2 & 3.1 & 22.5 & 69.4 & 5.6 & 0.7 & 98.7 & 7.9 \\
\hline & 3 & 133 & 101 & 71 & 47 & 1 & 112.9 & 10.5 & 23.1 & 269.6 & 2.2 & 15.9 & 57.0 & 4.6 & 0.7 & 77.8 & 6.2 \\
\hline
\end{tabular}




\begin{tabular}{|c|c|c|c|c|c|c|c|c|c|c|c|c|c|c|c|c|c|}
\hline & 4 & 100 & 104 & 73 & 44 & 1 & 104.2 & 13.4 & 21.2 & 278.2 & 1.6 & 18.4 & 45.7 & 3.7 & 0.7 & 62.7 & 5.0 \\
\hline & 5 & 136 & 87 & 62 & 42 & 1 & 75.3 & 12.4 & 19.8 & 222.5 & 1.6 & 17.1 & 35.8 & 2.9 & 0.7 & 51.2 & 4.1 \\
\hline & 6 & 142 & 90 & 71 & 45 & 1 & 181.5 & 13.0 & 38.3 & 362.6 & 2.9 & 22.0 & 66.3 & 5.3 & 0.7 & 92.8 & 7.4 \\
\hline & 7 & 160 & 181 & 170 & 80 & 1 & 383.7 & 17.0 & 107.7 & 221.3 & 6.3 & 42.4 & 73.8 & 5.9 & 0.8 & 87.6 & 7.0 \\
\hline & 8 & 292 & 97 & 84 & 55 & 0 & 182.1 & 18.3 & 33.7 & 522.5 & 1.8 & 26.2 & 55.7 & 4.5 & 0.8 & 72.4 & 5.8 \\
\hline & 9 & 109 & 121 & 93 & 52 & 0 & 244.0 & 21.0 & 27.0 & 373.7 & 1.3 & 27.4 & 72.0 & 5.8 & 0.8 & 89.1 & 7.1 \\
\hline & 10 & 228 & 121 & 104 & 64 & 1 & 528.2 & 43.7 & 72.9 & 638.8 & 1.7 & 60.9 & 70.4 & 5.6 & 0.8 & 88.3 & 7.1 \\
\hline & 11 & 111 & 107 & 86 & 48 & 1 & 78.0 & 7.2 & 17.0 & 146.5 & 2.4 & 11.2 & 56.3 & 4.5 & 0.7 & 75.4 & 6.0 \\
\hline & 12 & 82 & 118 & 81 & 45 & 0 & 281.3 & 14.3 & 30.6 & 305.8 & 2.1 & 21.4 & 105.7 & 8.5 & 0.8 & 133.7 & 10.7 \\
\hline & 13 & 172 & 64 & 55 & 36 & 0 & 108.8 & 10.5 & 33.1 & 223.4 & 3.2 & 18.3 & 48.3 & 3.9 & 0.7 & 74.1 & 5.9 \\
\hline & 14 & 99 & 107 & 74 & 45 & 0 & 186.3 & 9.3 & 33.8 & 287.4 & 3.6 & 17.3 & 86.7 & 6.9 & 0.8 & 113.2 & 9.1 \\
\hline & 15 & 120 & 82 & 67 & 41 & 1 & 107.8 & 10.1 & 36.5 & 270.9 & 3.6 & 18.7 & 46.7 & 3.7 & 0.7 & 68.0 & 5.4 \\
\hline & 16 & 159 & 108 & 87 & 53 & 0 & 396.0 & 31.4 & 33.7 & 581.3 & 1.1 & 39.3 & 81.2 & 6.5 & 0.8 & 102.7 & 8.2 \\
\hline & 17 & 105 & 76 & 55 & 36 & 1 & 122.0 & 8.3 & 30.7 & 211.1 & 3.7 & 15.5 & 63.4 & 5.1 & 0.6 & 98.0 & 7.8 \\
\hline & 18 & 131 & 68 & 58 & 36 & 1 & 215.9 & 14.1 & 24.9 & 176.8 & 1.8 & 20.0 & 87.7 & 7.0 & 0.7 & 135.0 & 10.8 \\
\hline & 19 & 82 & 88 & 71 & 38 & 1 & 139.2 & 13.9 & 22.4 & 171.9 & 1.6 & 19.1 & 59.2 & 4.7 & 0.7 & 85.0 & 6.8 \\
\hline & 20 & 274 & 58 & 50 & 35 & 1 & 174.5 & 11.0 & 54.6 & 502.0 & 5.0 & 23.8 & 58.6 & 4.7 & 0.6 & 97.7 & 7.8 \\
\hline & 21 & 106 & 48 & 39 & 26 & 1 & 81.9 & 8.5 & 53.7 & 150.7 & 6.3 & 21.2 & 31.5 & 2.5 & 0.5 & 63.1 & 5.1 \\
\hline & 22 & 76 & 89 & 73 & 38 & 0 & 81.8 & 8.8 & 24.2 & 286.0 & 2.7 & 14.5 & 45.3 & 3.6 & 0.7 & 61.0 & 4.9 \\
\hline & 23 & 138 & 89 & 57 & 41 & 1 & 278.8 & 31.2 & 36.9 & 585.9 & 1.2 & 39.8 & 56.6 & 4.5 & 0.7 & 81.4 & 6.5 \\
\hline & 24 & 115 & 96 & 80 & 45 & 0 & 202.0 & 25.4 & 25.9 & 527.3 & 1.0 & 31.5 & 51.7 & 4.1 & 0.8 & 67.3 & 5.4 \\
\hline & 1 & 118 & 100 & 95 & 49 & 1 & 167.9 & 17.1 & 4.4 & 159.5 & 0.3 & 18.1 & 75.4 & 6.0 & 0.8 & 99.5 & 8.0 \\
\hline & 2 & 110 & 64 & 55 & 33 & 1 & 157.5 & 20.7 & 17.8 & 243.0 & 0.9 & 24.9 & 51.5 & 4.1 & 0.6 & 81.2 & 6.5 \\
\hline & 3 & 180 & 72 & 55 & 38 & 2 & 447.5 & 26.1 & 30.2 & 356.0 & 1.2 & 33.2 & 109.0 & 8.7 & 0.6 & 168.8 & 13.5 \\
\hline & 4 & 118 & 73 & 53 & 35 & 1 & 202.4 & 19.5 & 19.2 & 280.5 & 1.0 & 24.0 & 68.4 & 5 & 0.7 & 04.4 & 8.4 \\
\hline & 5 & 141 & 110 & 78 & 50 & 1 & 392.8 & 33.3 & 4.7 & 214.7 & 0.1 & 34.4 & 93.1 & 7.5 & 0.8 & 122.1 & 9.8 \\
\hline & 1 & 92 & 92 & 82 & 42 & 1 & 2067.2 & 260.7 & 70.3 & 217.3 & 0.3 & 277.2 & 61.3 & .9 & 0.7 & .0 & 6.7 \\
\hline & 2 & 95 & 129 & 98 & 51 & 1 & 133.3 & 16. & 3.7 & 187.7 & 0.2 & 17.0 & & & 0.8 & 81.6 & 6.5 \\
\hline & & 96 & 110 & 81 & 46 & 0 & 172.1 & 21. & 6.3 & 107.7 & 0.3 & 22.5 & 62. & 5 & 0.8 & 78.9 & 6.3 \\
\hline & 4 & 139 & 65 & 52 & 34 & 0 & 472.7 & 28.6 & 52.7 & 235.1 & 1.8 & 41.0 & 93.9 & 7.5 & 0.7 & 143.4 & 11.5 \\
\hline & 5 & 166 & 143 & 121 & 67 & 1 & 126.7 & 10.3 & 12.6 & 241.9 & 1.2 & 13.2 & 77.0 & 6.2 & 0.8 & 94.1 & 7.5 \\
\hline & 1 & 194 & 120 & 104 & 63 & 2 & 262.1 & 16.5 & 47.9 & 198.5 & 2.9 & 27.8 & 76.8 & 6.1 & 0.8 & 100.0 & 8.0 \\
\hline & 2 & 169 & 103 & 101 & 55 & 1 & 258.8 & 22.4 & 71.6 & 239.0 & 3.2 & 39.2 & 53.8 & 4.3 & 0.8 & 70.4 & 5.6 \\
\hline & 3 & 148 & 92 & 86 & 48 & 1 & 194.7 & 16.0 & 60.6 & 153.1 & 3.8 & 30.2 & 52. & 4.2 & 0.7 & 71.9 & 5.8 \\
\hline & 4 & 106 & 96 & 91 & 47 & 2 & 415.1 & 25.4 & 106.7 & 195.8 & 4.2 & 50.5 & 67.1 & 5.4 & 0.7 & 97.2 & 7.8 \\
\hline & 5 & 185 & 158 & 123 & 74 & 1 & 226.0 & 22.1 & 41.8 & 216.9 & 1.9 & 31.9 & 57.7 & 4.6 & 0.8 & 69.5 & 5.6 \\
\hline & 6 & 84 & 62 & 48 & 30 & 2 & 701.2 & 118.0 & 168.7 & 529.1 & 1.4 & 157.6 & 36.5 & 2.9 & 0.6 & 8 & 5.3 \\
\hline & 7 & 131 & 75 & 64 & 40 & 2 & & & 78.0 & 150.8 & 1. & & & 8 & 0.7 & .4 & 5.8 \\
\hline & 8 & 104 & 71 & 61 & 37 & 2 & 400.9 & 45.2 & 79.7 & 191.7 & 1.8 & 63.9 & 51.4 & 4.1 & 0.6 & 82.8 & 6.6 \\
\hline & 1 & 183 & 93 & 66 & 46 & 0 & & 16. & 39.8 & 342.4 & 2.5 & 25.5 & 49.8 & 4.0 & 0.7 & 67.4 & 5.4 \\
\hline & 2 & 220 & 141 & 114 & 70 & 0 & 224.4 & 14. & 32.3 & 304.1 & 2. & 22.3 & 81. & 6.5 & 0.8 & 97.5 & 7.8 \\
\hline & 3 & 95 & 100 & 83 & 44 & 0 & 138.4 & 15. & 24.0 & 241.1 & 1.6 & 20.7 & 54. & 4.3 & 0.8 & 70.0 & 5.6 \\
\hline & 4 & 175 & 126 & 115 & 63 & 0 & 146.3 & 17.2 & 27.9 & 342.0 & 1.6 & 23.7 & 49. & 4.0 & 0.8 & 60.5 & 4.8 \\
\hline & 1 & 95 & 116 & 85 & 47 & 1 & 160.3 & 17.5 & 17.3 & 211.6 & 1.0 & 21.6 & 60.4 & 4.8 & 0.8 & 79.9 & 6.4 \\
\hline & 2 & 135 & 145 & 125 & 64 & 1 & & 14.1 & 24.1 & 218.6 & 1.7 & 19.8 & 47.7 & 3.8 & 0.8 & 58.6 & 4.7 \\
\hline & 3 & 100 & 77 & 72 & 38 & 1 & & 24.3 & 32.8 & 280.0 & 1.4 & 32.0 & 41 & 3.3 & 0.7 & 60.4 & 4.8 \\
\hline & 4 & 130 & 107 & 93 & 51 & 1 & 204.0 & 18.0 & 33.0 & 288.2 & 1.8 & 25.8 & 64.1 & 5.1 & 0.8 & 84.4 & 6.8 \\
\hline & 5 & 210 & 122 & 113 & 64 & 0 & & & 24.6 & 298.7 & 1.3 & 24.3 & 61.2 & 4.9 & 0.8 & 74.6 & 6.0 \\
\hline & 1 & 232 & 108 & 106 & 60 & 0 & & 11.9 & 33.8 & 46.4 & 2.8 & 19.8 & 24.8 & 2.0 & 0.8 & 31.1 & 2.5 \\
\hline & 2 & 276 & 13 & 114 & 72 & 1 & & 6 & 17 & & 2. & 3 & & 3.3 & 8 & & 4.1 \\
\hline & 3 & 130 & 135 & 97 & 58 & 0 & 326 & 25 & 73 & & 2.9 & 42 & 62 & 5. & 8 & 76.8 & 6.1 \\
\hline & 4 & 106 & 75 & 5 & 36 & 1 & 392.9 & 5 & 105.3 & 208.2 & 2. & 8 & & 3.4 & 0.7 & 65.8 & 5.3 \\
\hline & 5 & 145 & 117 & 90 & 55 & 0 & 93.7 & 11 & 34.7 & 51.9 & 3.1 & 19.3 & 39 & 3.2 & 0.8 & 50.2 & 4.0 \\
\hline & 6 & 168 & 194 & 152 & 82 & 0 & 125.7 & 13. & 41.4 & 97.1 & 3.0 & 23.5 & 43. & 3.5 & 0.9 & 49.9 & 4.0 \\
\hline & 7 & 192 & 83 & 72 & 45 & 2 & 328.0 & 31.9 & 47.6 & 37.9 & 1.5 & 43.1 & 62.5 & 5.0 & 0.7 & 89.9 & 7.2 \\
\hline & 8 & 171 & 110 & 85 & 54 & 0 & 125.4 & 14.4 & 42.5 & 88.8 & 2.9 & 24.4 & 42. & 3.4 & 0.8 & 53.7 & 4.3 \\
\hline & 9 & 93 & 112 & 90 & 47 & 1 & 134.5 & 14.8 & 54.1 & 79.9 & 3.7 & 27.5 & 40.1 & 3.2 & 0.7 & 53.8 & 4.3 \\
\hline & 10 & 204 & 106 & 91 & 56 & 1 & & 5.7 & 42.2 & 97.1 & 7.4 & 15.6 & 90.0 & 7.2 & 0.8 & 118.9 & 9.5 \\
\hline & 11 & 215 & 101 & 82 & 54 & 1 & & 16.7 & 47.5 & 77.2 & 2.8 & 27.8 & 45.2 & 3.6 & 0.8 & 60.1 & 4.8 \\
\hline & 12 & 102 & 86 & 75 & 41 & 1 & & & 41.5 & 34.5 & 2.9 & 24.1 & 41.1 & 3.3 & 0.7 & 58.6 & 4.7 \\
\hline & 13 & 80 & 73 & 55 & 33 & 1 & & & & & 2.9 & 37 & & & 6 & & 3.9 \\
\hline & 14 & 124 & 124 & 99 & 55 & 1 & & & 42.7 & 63.3 & 3.2 & 23.3 & 49 & 3.9 & 8 & 63.1 & 5.1 \\
\hline & 15 & 215 & 292 & 246 & 119 & 1 & & 12 & 38.7 & 93.9 & 3.2 & 21.4 & 54. & 4.4 & 0.9 & 60.7 & 4.9 \\
\hline & 16 & 135 & 270 & 217 & 93 & 1 & & & 35.4 & 67.8 & 3.1 & 19.8 & 51 & 4.1 & 0.9 & 58.7 & 4.7 \\
\hline & 17 & 233 & 302 & 239 & 123 & 1 & 147.8 & 12 & 40.9 & 100.8 & 3.3 & 22.1 & 54. & 4.4 & 0.9 & 60.9 & 4.9 \\
\hline & 18 & 160 & 140 & 130 & 67 & 1 & 119.6 & 15 & 43.0 & 82.4 & 2.8 & 25.2 & 38. & 3.1 & 0.8 & 47.9 & 3.8 \\
\hline & 19 & 180 & 105 & 68 & 49 & 1 & 12 & 12 & 41.8 & 40.3 & 3.4 & 22.2 & 46.6 & 3.7 & 0.7 & 63.6 & 5.1 \\
\hline & 20 & 144 & 132 & 100 & 59 & 1 & 126 & 16 & 47.4 & 63.3 & 2.9 & 27.3 & 37.9 & 3.0 & 0.8 & 48.1 & 3.8 \\
\hline & 21 & 94 & 140 & 105 & 54 & 1 & 122.8 & 11.8 & 40.4 & 42.6 & 3.4 & 21.3 & 47.2 & 3.8 & 0.8 & 60.5 & 4.8 \\
\hline & 22 & 109 & 108 & 66 & 44 & 0 & 106.4 & 17.2 & 61.1 & 53.9 & 3.5 & 31.6 & 27.7 & 2.2 & 0.8 & 36.7 & 2.9 \\
\hline
\end{tabular}




\begin{tabular}{|c|c|c|c|c|c|c|c|c|c|c|c|c|c|c|c|c|c|}
\hline & 23 & 112 & 125 & 98 & 53 & 0 & 101.3 & 9.2 & 22.4 & 23.2 & 2.4 & 14.5 & 57.3 & 4.6 & 0.8 & 70.6 & 5.6 \\
\hline & 24 & 143 & 112 & 86 & 53 & 1 & 96.4 & 13.6 & 38.2 & 75.5 & 2.8 & 22.6 & 35.0 & 2.8 & 0.8 & 46.1 & 3.7 \\
\hline & 25 & 92 & 80 & 53 & 35 & 1 & 119.0 & 18.6 & 51.2 & 0.0 & 2.8 & 30.6 & 32.0 & 2.6 & 0.6 & 49.3 & 3.9 \\
\hline \multirow[t]{28}{*}{ GAL14 } & 1 & 272 & 184 & 158 & 92 & 1 & 191.6 & 16.4 & 47.0 & 140.4 & 2.9 & 27.4 & 57.0 & 4.6 & 0.9 & 66.5 & 5.3 \\
\hline & 2 & 154 & 117 & 98 & 57 & 1 & 152.6 & 14.4 & 43.1 & 77.2 & 3.0 & 24.5 & 51.0 & 4.1 & 0.8 & 65.8 & 5.3 \\
\hline & 3 & 262 & 75 & 64 & 43 & 2 & 168.7 & 16.1 & 48.8 & 58.0 & 3.0 & 27.5 & 50.2 & 4.0 & 0.7 & 74.8 & 6.0 \\
\hline & 4 & 91 & 152 & 112 & 55 & 1 & 171.1 & 17.8 & 34.2 & 52.9 & 1.9 & 25.8 & 54.3 & 4.3 & 0.8 & 68.3 & 5.5 \\
\hline & 5 & 311 & 84 & 72 & 49 & 1 & 163.5 & 17.1 & 47.5 & 92.2 & 2.8 & 28.2 & 47.4 & 3.8 & 0.7 & 65.9 & 5.3 \\
\hline & 6 & 300 & 63 & 46 & 35 & 1 & 162.3 & 15.9 & 62.2 & 258.2 & 3.9 & 30.5 & 43.3 & 3.5 & 0.6 & 70.9 & 5.7 \\
\hline & 7 & 151 & 68 & 54 & 36 & 1 & 147.1 & 16.4 & 53.1 & 1214.0 & 3.2 & 28.9 & 39.8 & 3.2 & 0.6 & 62.4 & 5.0 \\
\hline & 8 & 130 & 96 & 82 & 47 & 1 & 162.5 & 15.8 & 50.5 & 128.5 & 3.2 & 27.7 & 48.0 & 3.8 & 0.7 & 65.6 & 5.3 \\
\hline & 9 & 77 & 93 & 72 & 39 & 1 & 178.4 & 16.7 & 57.0 & 370.7 & 3.4 & 30.1 & 48.1 & 3.8 & 0.7 & 69.2 & 5.5 \\
\hline & 10 & 110 & 164 & 111 & 61 & 1 & 163.1 & 13.8 & 42.4 & 115.5 & 3.1 & 23.8 & 56.0 & 4.5 & 0.8 & 69.6 & 5.6 \\
\hline & 11 & 224 & 171 & 128 & 80 & 1 & 184.2 & 14.8 & 44.6 & 0.9 & 3.0 & 25.3 & 59.8 & 4.8 & 0.8 & 71.4 & 5.7 \\
\hline & 12 & 100 & 177 & 146 & 65 & 1 & 179.9 & 18.1 & 37.6 & 65.5 & 2.1 & 26.9 & 54.8 & 4.4 & 0.8 & 66.4 & 5.3 \\
\hline & 13 & 180 & 138 & 89 & 61 & 1 & 167.2 & 15.7 & 46.0 & 55.9 & 2.9 & 26.5 & 51.8 & 4.1 & 0.8 & 65.6 & 5.2 \\
\hline & 14 & 75 & 90 & 59 & 36 & 1 & 146.1 & 15.5 & 53.4 & 182.8 & 3.4 & 28.1 & 42.5 & 3.4 & 0.7 & 63.6 & 5.1 \\
\hline & 15 & 170 & 74 & 65 & 41 & 1 & 308.0 & 28.7 & 87.0 & 187.2 & 3.0 & 49.1 & 51.3 & 4.1 & 0.7 & 75.8 & 6.1 \\
\hline & 16 & 125 & 70 & 55 & 36 & 2 & 129.5 & 14.5 & 59.5 & 168.6 & 4.1 & 28.5 & 37.1 & 3.0 & 0.6 & 60.9 & 4.9 \\
\hline & 17 & 71 & 104 & 87 & 41 & 0 & 181.8 & 22.2 & 58.8 & 58.0 & 2.6 & 36.0 & 41.4 & 3.3 & 0.8 & 53.1 & 4.3 \\
\hline & 18 & 110 & 102 & 73 & 45 & 1 & 145.4 & 15.3 & 48.8 & 111.8 & 3.2 & 26.7 & 44.5 & 3.6 & 0.7 & 61.5 & 4.9 \\
\hline & 19 & 192 & 95 & 68 & 48 & 1 & 148.6 & 17.0 & 56.0 & 29.5 & 3.3 & 30.2 & 40.5 & 3.2 & 0.7 & 56.1 & 4.5 \\
\hline & 1 & 155 & 80 & 63 & 41 & 0 & 237.5 & 10.4 & 83.1 & 145.0 & 8.0 & 29.9 & 64.7 & 9.4 & 0.7 & 92.6 & 13.4 \\
\hline & 2 & 167 & 113 & 81 & 54 & 0 & 194.4 & 5.7 & 57.9 & 112.6 & 10.2 & 19.3 & 82.1 & 4.9 & 0.8 & 106.2 & 6.4 \\
\hline & 3 & 218 & 60 & 51 & 35 & 1 & 123.8 & 6.7 & 82.5 & 84.8 & 12.3 & 26.1 & 38.8 & 2.3 & 0.6 & 63.5 & 3.8 \\
\hline & & 162 & 100 & 81 & 50 & 0 & 109.4 & 5.3 & 37.2 & 93.8 & 7.0 & 14.1 & 63.3 & 11.8 & 0.8 & 83.3 & 15.5 \\
\hline & 5 & 156 & 70 & 60 & 38 & 0 & 52.0 & 4.6 & 30.5 & 53.2 & 6.6 & 11.8 & 36.0 & 27.9 & 0.7 & 53.6 & 41.5 \\
\hline & 1 & 117 & 94 & 58 & 41 & 2 & 315.6 & 15.7 & 89.4 & 341.8 & 5.7 & 36.7 & 69.8 & 5.6 & 0.7 & 107.3 & 8.6 \\
\hline & 2 & 164 & 80 & 68 & 44 & 2 & 244.1 & 38.5 & 47.5 & 392.8 & 1.2 & 49.7 & 40.1 & 3.2 & 0.7 & 59.0 & 4.7 \\
\hline & 3 & 100 & 92 & 70 & 42 & 1 & 344.2 & 50.0 & 69.2 & 382.8 & 1.4 & 66.3 & 42.5 & 3.4 & 0.7 & 59.6 & 4.8 \\
\hline & 4 & 85 & 78 & 79 & 37 & 1 & 240.3 & 29.6 & 66.7 & 428.7 & 2.3 & 45.3 & 43.2 & 3.5 & 0.7 & 63.2 & 5.1 \\
\hline
\end{tabular}

\begin{tabular}{|c|c|c|c|c|c|c|c|c|c|c|c|c|c|c|c|c|c|}
\hline \multicolumn{18}{|l|}{ North V } \\
\hline WL & 1 & 135 & 53 & 45 & 29 & 0 & 99.1 & 2.9 & 25.6 & 1325.3 & 8.9 & 8.9 & $7 / .2$ & 6.2 & 0.6 & 135.9 & 10.9 \\
\hline & 2 & 130 & 64 & 55 & 34 & 0 & 53.2 & 1.1 & 19.7 & 366.3 & 17.2 & 5.8 & 70.1 & 5.6 & 0.6 & 111.1 & 8.9 \\
\hline & M1 & 118 & 64 & 55 & 34 & - & 23.0 & 1.0 & 8.5 & 497.1 & 8.1 & 3.0 & 51.5 & 4.1 & 0.6 & 79.6 & 6.4 \\
\hline & 1 & 120 & 115 & 115 & 55 & 1 & 100.0 & 6.1 & 22.8 & 389.9 & 3.7 & 11.5 & 68.6 & 5.5 & 0.8 & 88.5 & 7.1 \\
\hline & 2 & 169 & 89 & 89 & 49 & 1 & 84.6 & 4.1 & 19.4 & 425.0 & 4.7 & 8.7 & 75.6 & 6.1 & 0.7 & 103.6 & 8.3 \\
\hline & 3 & 138 & 93 & 80 & 47 & 1 & 61.3 & 3.7 & 16.7 & 378.9 & 4.5 & 7.7 & 61.9 & 5.0 & 0.7 & 85.5 & 6.8 \\
\hline & 4 & 125 & 77 & 77 & 42 & 1 & 111.0 & 5.7 & 29.2 & 483.8 & 5.1 & 12.6 & 69.2 & 5.5 & 0.7 & 100.9 & 8.1 \\
\hline & M1 & 103 & 81 & 70 & 40 & - & 95.9 & 6.1 & 23.9 & 484.8 & 3.9 & 11.7 & 64.1 & 5.1 & 0.7 & 90.6 & 7.2 \\
\hline & M2 & 106 & 55 & 47 & 30 & - & 72.4 & 5.2 & 22.1 & 429.0 & 4.2 & 10.4 & 54.3 & 4.3 & 0.6 & 94.0 & 7.5 \\
\hline & M3 & 153 & 69 & 59 & 38 & - & 71.9 & 5.1 & 15.4 & 355.6 & 3.0 & 8.7 & 64.7 & 5.2 & 0.7 & 96.4 & 7.7 \\
\hline WLC & 1 & 154 & 75 & 64 & 40 & 1 & 69.7 & 8.6 & 8.8 & 450.6 & 1.0 & 10.7 & 51.0 & 4.1 & 0.7 & 74.2 & 5.9 \\
\hline & 2 & 92 & 96 & 60 & 37 & 1 & 66.0 & 7.4 & 5.4 & 428.6 & 0.7 & 8.7 & 59.1 & 4.7 & 0.7 & 85.2 & 6.8 \\
\hline & 3 & 112 & 107 & 86 & 48 & 1 & 60.4 & 5.8 & 6.3 & 365.9 & 1.1 & 7.3 & 64.1 & 5.1 & 0.8 & 85.1 & 6.8 \\
\hline & 4 & 161 & 85 & 84 & 46 & 1 & 48.5 & 7.6 & 8.0 & 394.4 & 1.1 & 9.4 & 40.3 & 3.2 & 0.7 & 55.3 & 4.4 \\
\hline & 5 & 127 & 90 & 84 & 44 & 1 & 58.5 & 6.4 & 6.9 & 355.0 & 1.1 & 8.0 & 56.8 & 4.5 & 0.7 & 77.9 & 6.2 \\
\hline WLO & 1 & 110 & 106 & 60 & 42 & 0 & 39.4 & 5.1 & 6.7 & 525.7 & 1.3 & 6.7 & 44.1 & 3.5 & 0.7 & 59.0 & 4.7 \\
\hline & 2 & 170 & 96 & 89 & 51 & 0 & 37.9 & 6.0 & 8.4 & 529.3 & 1.4 & 8.0 & 36.0 & 2.9 & 0.8 & 46.6 & 3.7 \\
\hline & 3 & 125 & 69 & 59 & 36 & 1 & 23.9 & 4.1 & 3.8 & 278.0 & 0.9 & 5.0 & 36.8 & 2.9 & 0.7 & 55.8 & 4.5 \\
\hline & 4 & 123 & 90 & 79 & 45 & 0 & 27.8 & 3.9 & 4.3 & 462.0 & 1.1 & 4.9 & 42.1 & 3.4 & 0.8 & 55.5 & 4.4 \\
\hline & 5 & 145 & 81 & 66 & 41 & 1 & 30.5 & 5.6 & 6.5 & 544.7 & 1.2 & 7.1 & 32.3 & 2.6 & 0.7 & 46.2 & 3.7 \\
\hline WL08 & 1 & 214 & 95 & 64 & 48 & 0 & 73.3 & 13.3 & 14.6 & 597.5 & 1.1 & 16.7 & 34.6 & 2.8 & 0.7 & 46.4 & 3.7 \\
\hline & 2 & 120 & 104 & 74 & 46 & 0 & 42.8 & 5.9 & 7.4 & 376.0 & 1.3 & 7.6 & 43.7 & 3.5 & 0.8 & 56.6 & 4.5 \\
\hline & 3 & 148 & 73 & 54 & 37 & 1 & 71.8 & 15.4 & 17.2 & 516.8 & 1.1 & 19.4 & 29.5 & 2.4 & 0.7 & 44.6 & 3.6 \\
\hline & 4 & 149 & 82 & 70 & 43 & 0 & 54.1 & 7.1 & 9.6 & 374.6 & 1.4 & 9.4 & 45.4 & 3.6 & 0.7 & 62.0 & 5.0 \\
\hline & 5 & 191 & 83 & 57 & 42 & 0 & 89.1 & 11.9 & 21.9 & 571.6 & 1.8 & 17.1 & 41.2 & 3.3 & 0.7 & 58.2 & 4.7 \\
\hline
\end{tabular}

${ }^{a} \mathrm{~L}$ - crystal length, W1 - crystal width (larger), W2 - crystal width (smaller), $\mathrm{R}^{*}$ - equivalent radius (i.e. the radius of a sphere with the same surface to volume ratio as the apatite crystal), $\mathrm{T}$ - number of crystal terminations, eU - effective Uranium (eU $=\mathrm{U}+0.235 \mathrm{Th}$ ), age $_{u c}$ - uncorrected age, age $e_{c}$ - corrected age, Ft - a-recoil correction factor after Gautheron and Tassan-Got (2010) *uncertainty in italics is the calculated analytical uncertainty; in normal font, for aliquots which yielded analytical uncertainty smaller than reproducibility of Durango aliquots, the uncertainty is given as $6 \%$ of the age; all uncertainties are given at the $1 \sigma$ level Aliquots numbers marked with "M" indicate multi-grain aliquots. 
Table 2. Zircon (U-Th)/He data ${ }^{\mathrm{a}}$.

\begin{tabular}{|c|c|c|c|c|c|c|c|c|c|c|c|c|c|c|c|}
\hline & No & $\begin{array}{c}\mathrm{L} \\
(\mu \mathrm{m})\end{array}$ & $\begin{array}{c}\text { W } \\
(\mu \mathrm{m})\end{array}$ & $\begin{array}{c}R^{*} \\
(\mu \mathrm{m})\end{array}$ & $\mathrm{T}$ & $\begin{array}{c}\mathrm{He} \\
(\mu \mathrm{cc} / \mathrm{g})\end{array}$ & $\begin{array}{c}\mathrm{U} \\
(\mathrm{ppm})\end{array}$ & $\begin{array}{c}\text { Th } \\
(\mathrm{ppm})\end{array}$ & $\mathrm{Th} / \mathrm{U}$ & $\begin{array}{c}\mathrm{eU} \\
(\mathrm{ppm})\end{array}$ & $\begin{array}{r}\operatorname{age}_{u c} \\
\quad(\mathrm{Ma}\end{array}$ & $1 \sigma^{*}$ & $\mathrm{Ft}$ & $\begin{array}{l}\mathrm{age}_{\mathrm{c}} \\
\quad(\mathrm{Ma})\end{array}$ & 10 \\
\hline \multirow[t]{4}{*}{ LD01 } & 1 & 605 & 150 & 101 & 2 & 37.6 & 586.0 & 765.3 & 1.31 & 765.9 & 393.2 & 39.3 & 0.9 & 445.8 & 44.6 \\
\hline & & 527 & 130 & 88 & 2 & 36.7 & 629.8 & 666.0 & 1.06 & 786.4 & 374.2 & 37.4 & 0.9 & 432.6 & 43.3 \\
\hline & 4 & 295 & 121 & 75 & 2 & 38.1 & 908.6 & 696.7 & 0.77 & 1072.3 & 286.6 & 28.7 & 0.8 & 339.6 & 34.0 \\
\hline & 5 & 406 & 91 & 62 & 2 & 30.9 & 1046.5 & 818.3 & 0.78 & 1238.8 & 202.6 & 20.3 & 0.8 & 248.9 & 24.9 \\
\hline \multirow[t]{4}{*}{ LD03 } & 1 & 226 & 90 & 56 & 2 & 9.0 & 175.0 & 225.4 & 1.29 & 228.0 & 319.3 & 31.9 & 0.8 & 403.1 & 40.3 \\
\hline & 2 & 180 & 71 & 44 & 2 & 12.6 & 182.5 & 256.4 & 1.40 & 242.8 & 416.0 & 41.6 & 0.7 & 562.9 & 56.3 \\
\hline & 3 & 205 & 90 & 55 & 2 & 10.5 & 185.4 & 228.8 & 1.23 & 239.2 & 352.9 & 35.3 & 0.8 & 448.4 & 44.8 \\
\hline & 4 & 160 & 67 & 41 & 2 & 9.4 & 210.7 & 211.9 & 1.01 & 260.5 & 290.6 & 29.1 & 0.7 & 401.4 & 40.1 \\
\hline \multirow[t]{8}{*}{ LD10 } & 1 & 420 & 104 & 70 & 2 & 19.5 & 1120.5 & 531.6 & 0.47 & 1245.4 & 128.3 & 12.8 & 0.8 & 153.7 & 15.4 \\
\hline & 2 & 187 & 76 & 47 & 2 & 17.7 & 1801.2 & 252.6 & 0.14 & 1860.5 & 78.3 & 7.8 & 0.8 & 102.6 & 10.3 \\
\hline & 5 & 265 & 78 & 52 & 2 & 27.7 & 2001.1 & 953.2 & 0.48 & 2225.1 & 102.1 & 10.2 & 0.8 & 131.2 & 13.1 \\
\hline & 1 & 238 & 88 & 55 & 2 & 29.2 & 1270.7 & 1478.8 & 1.16 & 1618.2 & 147.5 & 14.8 & 0.8 & 186.5 & 18.6 \\
\hline & 2 & 216 & 100 & 60 & 2 & 28.8 & 959.8 & 454.3 & 0.47 & 1066.6 & 219.5 & 22.0 & 0.8 & 271.7 & 27.2 \\
\hline & 3 & 168 & 62 & 40 & 2 & 25.4 & 808.7 & 562.5 & 0.70 & 940.9 & 219.1 & 21.9 & 0.7 & 306.9 & 30.7 \\
\hline & 4 & 180 & 73 & 45 & 2 & 23.7 & 614.4 & 442.4 & 0.72 & 718.3 & 266.7 & 26.7 & 0.8 & 356.1 & 35.6 \\
\hline & 5 & 202 & 102 & 60 & 2 & 29.6 & 703.0 & 440.8 & 0.63 & 806.6 & 296.3 & 29.6 & 0.8 & 367.7 & 36.8 \\
\hline
\end{tabular}
the zircon crystal), $T$ - number of crystal terminations, eU - effective Uranium (eU $=U+0.235 T h$ ) age - uncorrected age age $_{C}$ - corrected age, $\mathrm{Ft}$ - $\alpha$-recoil correction factor after Gautheron and Tassan-Got (2010)

${ }^{*}$ the uncertainty is given as $10 \%$ of the age; all uncertainties are given at the $1 \sigma$ level 
Table 3. Minimum and maximum thicknesses of the Mesozoic sedimentary layer, divided into chalk and 'other' sediments, used for the calculation of the thickness of the eroded basement and of the total early Paleogene denudation.

\begin{tabular}{|c|c|c|c|c|c|}
\hline \multirow{2}{*}{\multicolumn{2}{|c|}{ Locality }} & \multicolumn{4}{|c|}{ Thickness of eroded strata $(\mathrm{m})$} \\
\hline & & chalk & $\begin{array}{c}\text { other } \\
\text { sediments }\end{array}$ & basement & total \\
\hline \multirow[t]{2}{*}{ Cheviot } & $\min$ & 400 & 600 & 0 & 1000 \\
\hline & $\max$ & 200 & 400 & 900 & 1500 \\
\hline \multirow[t]{2}{*}{ N Southern Uplands } & $\min$ & 100 & 0 & 900 & 1000 \\
\hline & $\max$ & 0 & 0 & 1200 & 1200 \\
\hline \multirow[t]{2}{*}{ Corsewall Point } & $\min$ & 400 & 600 & 200 & 1000 \\
\hline & $\max$ & 200 & 400 & 900 & 1500 \\
\hline \multirow[t]{2}{*}{ Fleet } & $\min$ & 300 & 400 & 600 & 1300 \\
\hline & $\max$ & 100 & 400 & 1200 & 1700 \\
\hline \multirow[t]{2}{*}{ Portencorkie } & $\min$ & 200 & 400 & 300 & 900 \\
\hline & $\max$ & 0 & 0 & 1200 & 1200 \\
\hline \multirow[t]{2}{*}{ Criffell } & $\min$ & 600 & 1400 & 0 & 2000 \\
\hline & $\max$ & 500 & 1000 & 900 & 2400 \\
\hline \multirow[t]{3}{*}{ Lake District } & $\min$ & 400 & 900 & 300 & 1600 \\
\hline & $\max ^{*}$ & 600 & 1150 & - & - \\
\hline & $\max$ & 300 & 400 & 1400 & 2100 \\
\hline \multirow[t]{2}{*}{ Penmaenmawr } & $\min$ & 400 & 400 & 200 & 1000 \\
\hline & $\max$ & 0 & 0 & 1700 & 1700 \\
\hline \multirow[t]{2}{*}{ Llyn } & $\min$ & 100 & 400 & 500 & 1000 \\
\hline & $\max$ & 0 & 0 & 1300 & 1300 \\
\hline \multirow[t]{2}{*}{ Isle of Man† } & $\min$ & 400 & 900 & 0 & 1300 \\
\hline & $\max$ & 300 & 400 & 900 & 1600 \\
\hline \multirow[t]{2}{*}{ NE Ireland† } & $\min$ & 400 & 500 & 0 & 900 \\
\hline & $\max$ & 200 & 400 & 800 & 1400 \\
\hline \multirow[t]{2}{*}{ SE Ireland $†$} & $\min$ & 200 & 400 & 0 & 600 \\
\hline & $\max$ & 100 & 200 & 600 & 900 \\
\hline \multirow[t]{2}{*}{ N EISB $\ddagger$} & $\min$ & 700 & 1100 & 0 & 1800 \\
\hline & $\max$ & 400 & 1700 & 0 & 2100 \\
\hline \multirow[t]{2}{*}{ S EISB $\ddagger$} & $\min$ & 700 & 800 & 0 & 1500 \\
\hline & $\max$ & 400 & 1400 & 0 & 1800 \\
\hline
\end{tabular}

'Other sediments' are the Mesozoic sediments older than Late Cretaceous and include mostly Lower Jurassic and Triassic limestones, mudstones and sandstones; for geothermal gradients and parameters used in calculation see Supporting Information

* maximum estimate after Holliday (1993); for given parameters, these estimates produce a cooling amount that is higher than that derived from the LTT

$\dagger$ based on the thermal models of Cogné et al. (2016)

$\ddagger$ based on results of Lewis et al. (1992) 
Table 4. Ranges of parameters used in the calculation of the underplating-driven denudation and non-underplating driven rock uplift ${ }^{\mathrm{a}}$.

\begin{tabular}{|c|c|c|c|c|c|c|c|c|}
\hline Locality & $\begin{array}{c}\rho_{\mathrm{s}} \\
\left(\mathrm{g} / \mathrm{cm}^{3}\right)\end{array}$ & W (m) & $X(\mathrm{~km})$ & $\mathrm{T}(\mathrm{m})$ & $\mathrm{D}_{\text {total }}(\mathrm{m})$ & $D_{x}(m)$ & $\mathrm{D}_{\text {total-X }}(\mathrm{m})$ & $U_{t}(m)$ \\
\hline Cheviot & 2.4 & $0-100$ & 2.0 & $100-150$ & $1000-1500$ & 367 & $633-1133$ & $277-380$ \\
\hline N Scotland & 2.4 & $0-100$ & $2.0-3.0$ & $100-300$ & $1000-1300$ & 250 & $750-1050$ & 214-286 \\
\hline Corsewall Point & 2.4 & 400 & 3.0 & $0-50$ & $1000-1500$ & 219 & $781-1281$ & $292-404$ \\
\hline Fleet & 2.4 & 150 & $4.0-4.5$ & 200 & $1300-1700$ & 772 & $528-928$ & $205-298$ \\
\hline Portencorkie & 2.4 & 400 & 3.5 & $0-50$ & $900-1200$ & 442 & $458-758$ & $183-207$ \\
\hline Criffell & 2.3-2.4 & 300 & 6.0 & 100 & $2000-2400$ & 1457 & $543-943$ & $309-387$ \\
\hline Lake District & $2.5-2.7$ & 100 & $4.0-5.0$ & 250 & $1600-2100$ & 1055 & 545-1045 & $310-328$ \\
\hline Penmaenmawr & 2.4 & 100 & 5.0 & 50 & $1000-1700$ & 1783 & - & - \\
\hline Llyn & 2.4 & 100 & 5.0 & 50 & $1000-1400$ & 1783 & - & - \\
\hline Isle of Man & 2.4 & $300-400$ & $3.5-4.0$ & 100 & $1300-1600$ & 485 & $815-1115$ & $340-369$ \\
\hline NE Ireland & $2.3-2.4$ & 100 & $2.0-3.0$ & 100 & $900-1400$ & 253 & $647-1147$ & $340-369$ \\
\hline SE Ireland & $2.3-2.4$ & 100 & $2.0-3.0$ & 150 & $600-700$ & 79 & $521-621$ & $255-377$ \\
\hline N EISB & 2.1-2.3 & 400 & 6.0 & 0 & $1800-2100$ & 1357 & $443-743$ & 206-291 \\
\hline \multirow[t]{2}{*}{ S EISB } & $2,1-2,3$ & 400 & 5,0 & 0 & $1500-1800$ & 990 & $510-810$ & 218-307 \\
\hline & & & & & & & Average: & $256-323$ \\
\hline \multicolumn{9}{|c|}{ 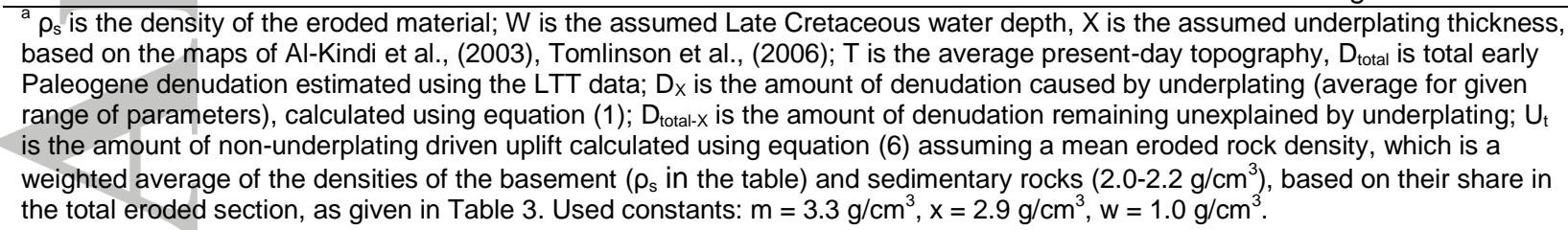 } \\
\hline
\end{tabular}

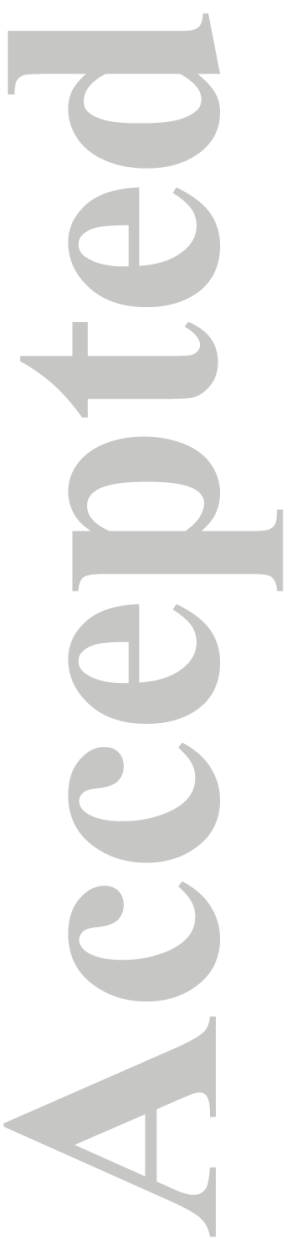




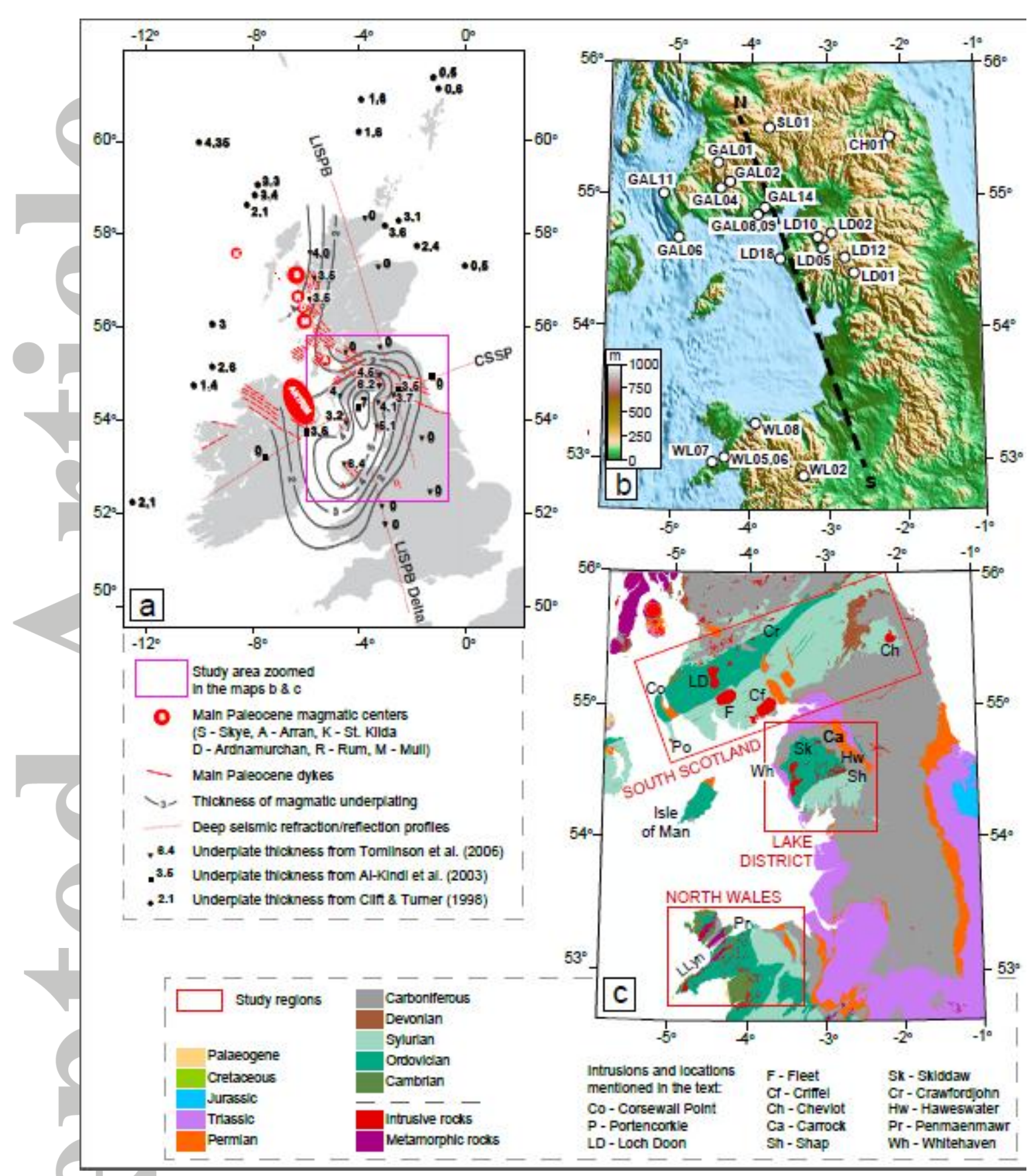

Figure 1. Maps of the study area. (a) Map of the British Isles showing the study area, locations of main Paleocene dykes and magmatic centers, and thickness of magmatic underplating; LISPB - the Lithospheric Seismic Profile in Britain (Bamford et al., 1978), CSSP - the Caledonian Suture Seismic Experiment (Al-Kindi et al., 2003; Bott et al., 1985) (modified from Tomlinson et al., 2006). (b) Topographic map of the study area with sample locations (white circles), based on the ETOPO1 Global relief model data; N-S thick, black line is a quasi-north-south oriented profile shown in Figure 2. (c) Geological map of the study area, based on the Digital Geological Map of Great Britain 1:650 000 (DiGMapGB-625), British Geological Survey materials (C) NERC (2016), with study regions and locations of intrusions and other places mentioned in the text. 

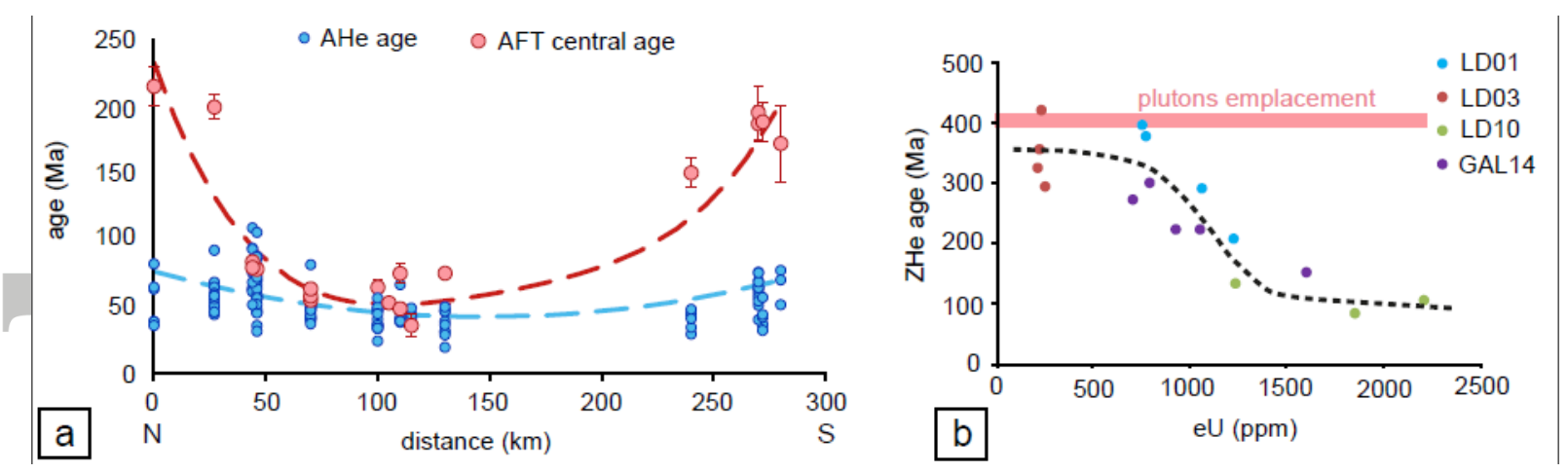

Figure 2. Regional summary of low temperature thermochronological data. a: Apatite fission track central ages and apatite (U-Th-Sm)/He ages with error bars $(1 \sigma)$ versus the distance along a quasi-north-south oriented profile. Samples GAL06, GAL11 and CH01 were not included as they are located far from the profile line (see Figure 1 for profile line location). The location of other samples was interpolated on the profile line. Dashed lines are polynomial trend lines of the AFT central ages (red circles), uncorrected AHe ages (blue circles). b: Uncorrected zircon (U-Th-Sm)/He ages plotted versus effective uranium (eU) The dashed line indicates a trend of the age decreasing with eU; the shaded, red area shows the age of plutons emplacement (Brown et al., 1968; Rundle, 1979).

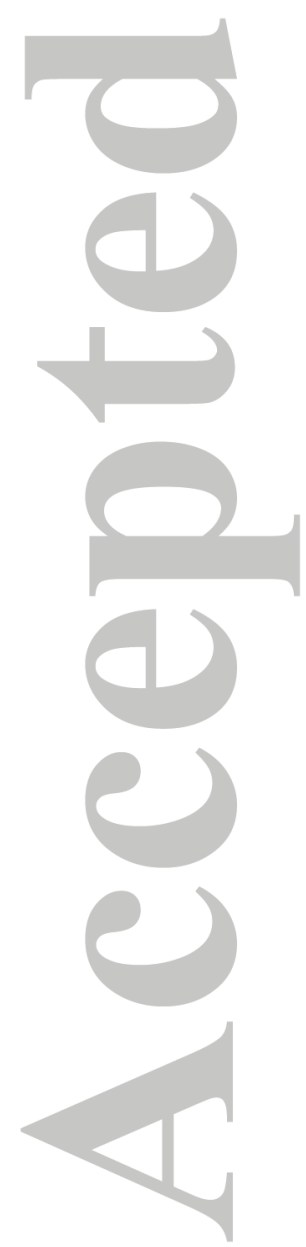




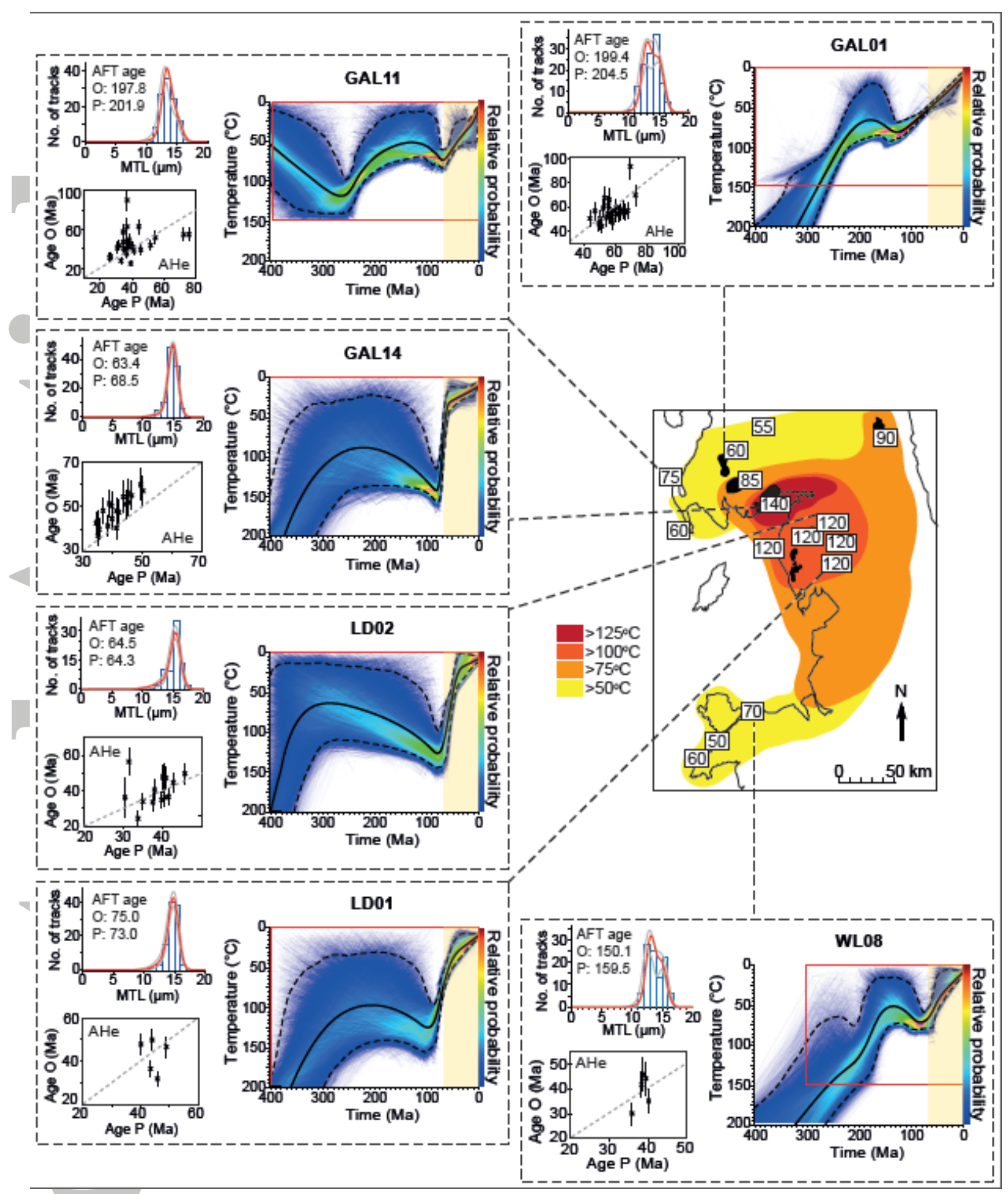

Figure 3. Map of the Late Cretaceous paleotemperatures, exemplary thermal histories and data predictions for expected models extracted from inverse modeling, using QTQt

(Gallagher, 2012). Thermal history graphs: thick black line is the expected model and dashed black lines are the $95 \%$ credible intervals; underlying color plot presents the probability density of the thermal history (red - high probability, blue - low probability); thin red line defining a box shows the general range of prior; the light yellow shadow marks the Cenozoic era, 66-0 Ma. Model predictions plots: histograms show projected fission track length distributions (FTLD); the red and gray lines are the predicted FTLD and the 95\% credible intervals, respectively. The dashed line in the AHe predictions graph is a 1:1 line. $\mathrm{O}-$ observed age, $\mathrm{P}$ - predicted age. Error bars on the observed ages are $1 \sigma$. 


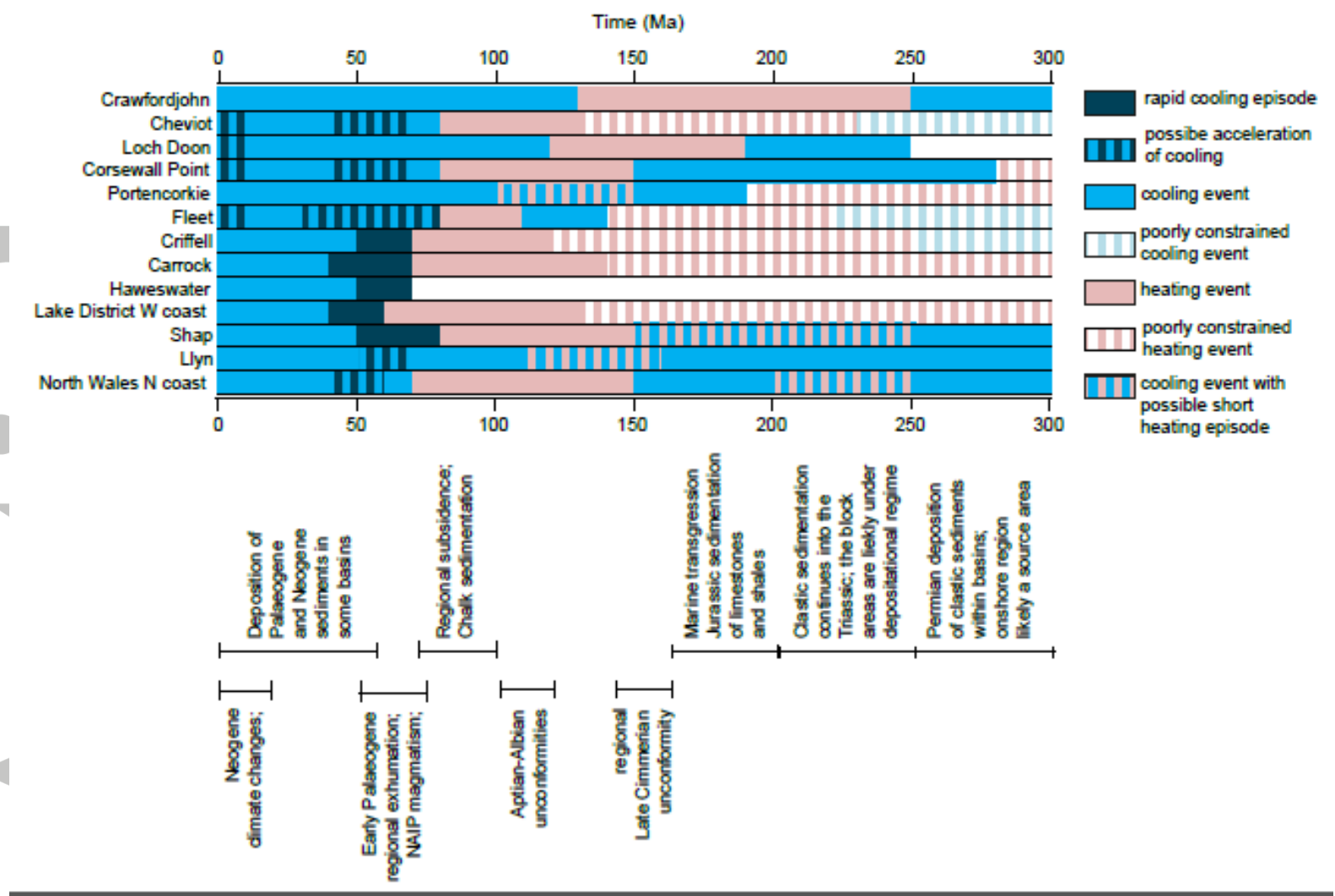

Figure 4. Compilation of cooling and re-heating events in the localities that have thermal histories extracted from QTQt inverse modeling. The localities are ordered along the quasinorth-south profile, see Figure 1c for locations. If more than one sample was analyzed for any site, the sample with the largest dataset has been chosen. Under the diagram, the key depositional and erosional events are marked along the time line. 


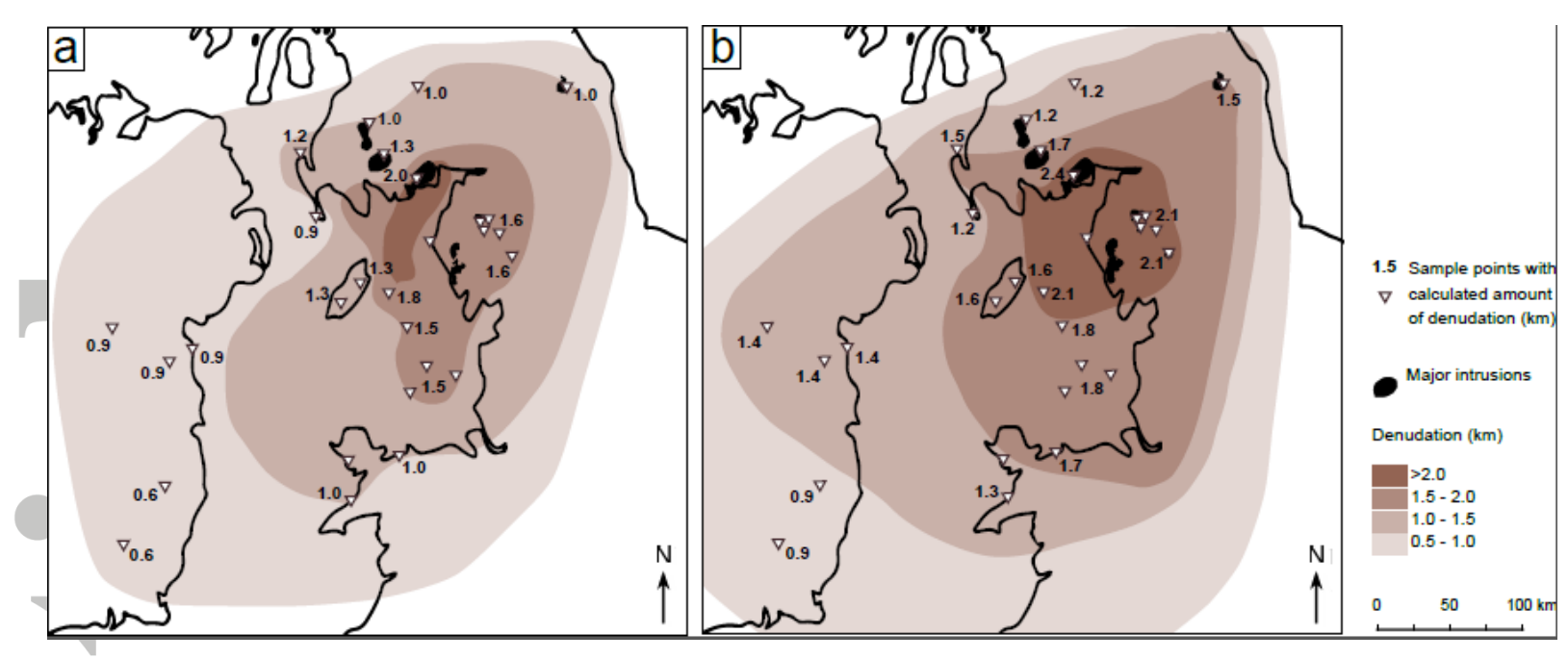

Figure 5. Estimates of the early Paleogene denudation in central west Britain derived from the AHe and AFT data and the QTQt thermal models; A-minimum estimate, B - maximum estimate.
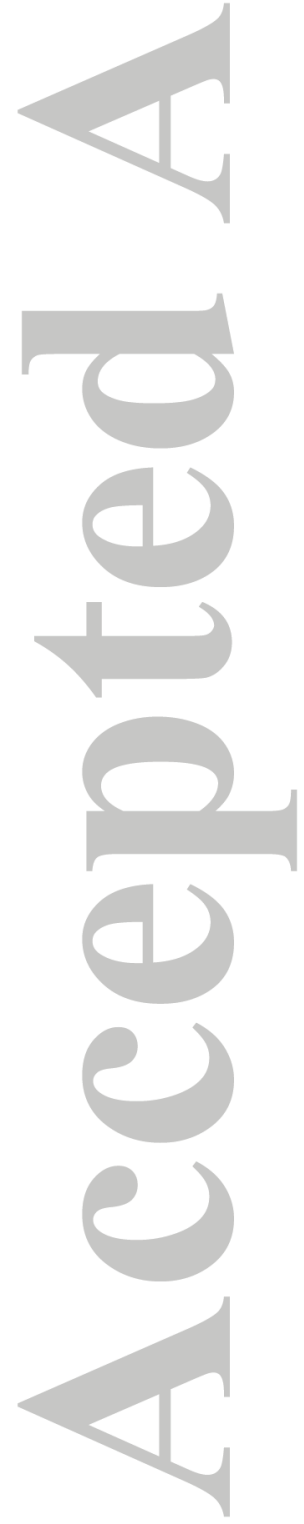